\title{
Changing Patterns of Expression and Subcellular Localization of TrkB in the Developing Visual System
}

\author{
Robert J. Cabelli, ${ }^{1}$ Karen L. Allendoerfer, ${ }^{1}$ Monte J. Radeke, ${ }^{2}$ Andrew A. Welcher, ${ }^{3}$ Stuart C. Feinstein, ${ }^{2}$ and \\ Carla J. Shatz 1 \\ ${ }^{1}$ Howard Hughes Medical Institute and Department of Molecular and Cell Biology, University of California at Berkeley, \\ Berkeley, California 94720, ${ }^{2}$ Neuroscience Research Institute and Department of Molecular, Cellular, and Developmental \\ Biology, University of California at Santa Barbara, Santa Barbara, California 93106, and ${ }^{3}$ AMGEN, Inc., Thousand Oaks, \\ California 91320
}

Neurotrophins play important roles in the survival, differentiation, and maintenance of CNS neurons. To begin to investigate specific roles for these factors in the mammalian visual system, we have examined the cellular localization of the neurotrophin receptor trkB within the developing cerebral cortex and thalamus of the ferret using extracellular domain-specific antibodies.

At prenatal ages (gestation is $41 \mathrm{~d}$ ), trkB-immunostained fibers were observed in the internal capsule and as two distinct fascicles within the intermediate zone of the cerebral cortex. The staining of these fiber tracts declined with increasing age, whereas soma and dendrite staining of cortical neurons was first evident in early postnatal life and increased during subsequent development. Staining of subplate neurons [by prenatal day 5 (P5)] was followed by staining of cortical layer 5 neurons (at P10). By P31, trkB immunoreactivity was particularly prominent in layers 3 and 5 but was absent from subplate neurons. Staining included cells, especially pyramidal neurons, in all cortical layers by $\mathrm{P} 45$, and this pattern was maintained into adulthood. The optic tract and fibers within the lateral geniculate nucleus (LGN) were also strongly trkB immunoreactive at prenatal ages. Cellular staining of a subset of LGN neurons, those within the C-layers and perigeniculate nucleus, was apparent by $\mathrm{P} 10$ and maintained until $\mathrm{P} 45$, when the adult pattern of highly trkB-immunoreactive neurons in all layers of the LGN first appeared.

The pattern of trkB immunoreactivity suggests that specific subsets of cortical and thalamic neurons may respond to neurotrophins such as brain-derived neurotrophic factor and/or NT-4/5 at discrete developmental times and locations. The appearance of trkB on axon fibers early in development and then on cell bodies and dendritic processes later is consistent with roles for both long-range and local, including autocrine and/or paracrine, delivery of neurotrophins in cell survival and maturation.

Key words: neurotrophins; cell death; cortex; subplate; LGN; subventricular zone; BDNF; NT-4/5
During mammalian visual system development, the initial phases of neurogenesis, axon outgrowth, and target recognition are followed by periods of selective cell death and remodeling of axonal projections. Subplate neurons of the cerebral cortex send pioneer axons through the internal capsule to subcortical targets, and they also serve as transient targets for ingrowing thalamic axons (for review, see Allendoerfer and Shatz, 1994). Shortly after lateral geniculate nucleus (LGN) axons leave visual subplate to invade

Received July 11, 1996; revised Sept. 18, 1996; accepted Sept. 23, 1996.

This work was supported by National Institutes of Health Grant EY02858 and the Alzheimer's and Related Disorders Association (C.J.S.), National Institutes of Health Grants EY06327 (R.J.C.) and NS07158 (K.L.A.), and National Institutes of Health Grant EY10739 and National Science Foundation (NSF) Grant IBN-9120836 (S.C.F.). C.J.S. is an investigator of the Howard Hughes Medical Institute. We thank Alicia Wright for assistance with immunohistochemistry, Dr. Andreas Hohn for assistance with fetal surgery and ${ }^{3} \mathrm{H}$-thymidine injections, Dr. Sue McConnell for allowing us to use her confocal microscope and Anjen Chenn for instruction in its use, and Drs. David Kaplan and Luis Parada for providing antibodies, pan-trk, anti-trkB.T1, and anti-trkBout. Peptides were synthesized by the University of California at Santa Barbara Advanced Instrumentation Center, a part of the Materials Research Laboratory Central Facilities, supported by the NSF under Award No. DMR-9123048.

Correspondence should be addressed to Dr. Robert J. Cabelli at his present address: Department of Cell and Neurobiology, 1333 San Pablo Street, BMT 401, University of Southern California School of Medicine, Los Angeles, CA 90033.

Karen Allendoerfer's present address: Division of Biology, 216-76, California Institute of Technology, Pasadena, CA 91125.

The first two authors (R.J.C. and K.L.A.) contributed equally to this study.

Copyright (C) 1996 Society for Neuroscience 0270-6474/96/167965-16\$05.00/0 their targets in cortical layer 4 (Ghosh and Shatz, 1992), 80\% of the subplate neurons in cat visual cortex are eliminated (Chun and Shatz, 1989), and the LGN axon terminals segregate into ocular dominance (OD) columns (Levay et al., 1978). Additional events in the sculpting of visual system connections include the death of excess or inappropriately projecting retinal ganglion cells (RGCs) (O'Leary et al., 1986; Williams et al., 1986; Henderson et al., 1988) and LGN neurons (Williams and Rakic, 1988), and the remodeling of RGC axon terminals into eye-specific layers in the LGN (Linden et al., 1981; Shatz, 1983).

The neurotrophins NGF, brain-derived neurotrophic factor (BDNF), NT-3, and NT-4/5 have been shown to promote cell survival and differentiation in various CNS systems. There is increasing evidence that neurotrophins may play a role in the development of the mammalian visual system. For example, BDNF promotes the survival of RGCs in culture (Johnson et al., 1986; Rodriguez-Tébar et al., 1989), whereas BDNF mRNA has been found in RGC targets (Rickman et al., 1992). BDNF message is present in layers $2 / 3$ and 5 of both visual and somatosensory cortex in monkey (Huntley et al., 1992) and ferret and cat (Lein et al., 1995). Moreover, regulation of BDNF mRNA expression by activity has been demonstrated in visual cortex by dark rearing followed by exposure to light or by monocular deprivation (Castrén et al., 1992; Bozzi et al., 1993; Schoups et al., 1995) and in somatosensory cortex in response to vibrissae stimulation 
trkB.FL

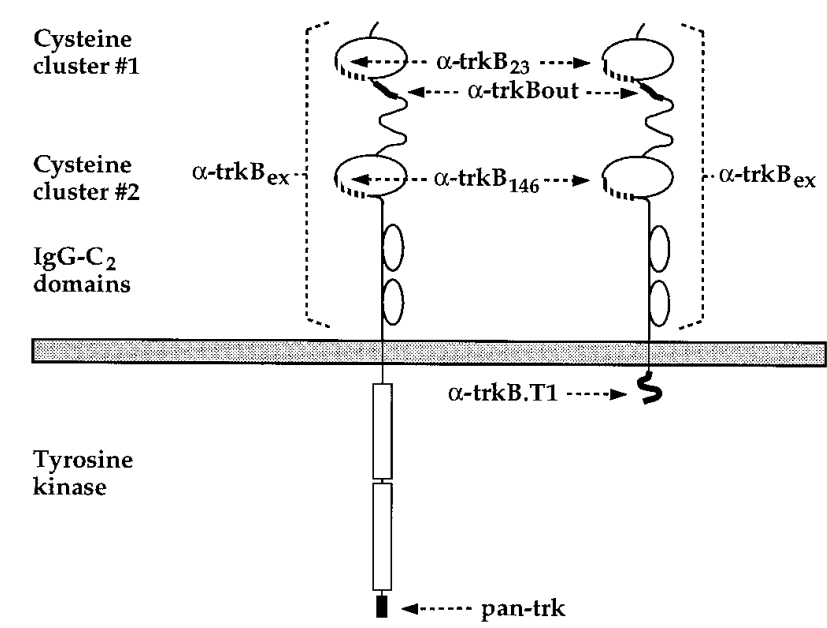

Figure 1. Schematic representation of the anti-trkB antibodies used in this study in the biochemical and immunohistochemical analysis of trkB. The arrows point to those protein sequences against which the particular antibodies were prepared.

(Rocamora et al., 1993). More recently, we have shown that infusion of excess NT-4/5 or BDNF, but not NT-3 or NGF, prevents the normal segregation of LGN afferents into eyespecific patches, as would be predicted if competition between axons for limiting amounts of target-derived NT-4/5 or BDNF played an instructive role in this process (Cabelli et al., 1995). Regulation of axon morphology by BDNF has also been demonstrated in vivo in the Xenopus retinotectal system (Cohen-Cory and Fraser, 1995). In a similar vein, Katz and coworkers have found that in vitro application of neurotrophins significantly alters the dendritic morphology of neurons in ferret visual cortex (McAllister et al., 1995), whereas in vivo application of NT-4/5 prevents the reduction in LGN cell soma size associated with monocular deprivation (Riddle et al., 1995).

The effects of BDNF and NT-4/5 are mediated through their receptor, trkB. Messenger RNAs encoding trkB are distributed widely throughout the CNS (Klein et al., 1990a,b). Although in some instances the pattern of expression of neurotrophins and their receptors is consistent with classical target-derived neurotrophic support (e.g., Phillips et al., 1990), evidence favoring autocrine or paracrine (Schechterson and Bothwell, 1992; Acheson et al., 1995) and even anterograde (von Bartheld et al., 1996) mechanisms of neurotrophin action has also been obtained.

We have used the chemical cross-linking of iodinated neurotrophins to demonstrate the presence of trkB within ferret visual system structures (Allendoerfer et al., 1994). This approach, however, is uninformative with respect to the cellular localization of trkB, a prerequisite for understanding the cellular basis of neurotrophin-trkB interactions. To identify the cells expressing trkB, we have carried out an immunohistochemical analysis of trkB expression during ferret visual system development.

\section{MATERIALS AND METHODS}

Animals. Forty-one fetal and postnatal ferrets ranging in age from embryonic day 30 (E30) to adult were used in this study (gestation is $41 \mathrm{~d}$ in the ferret). Timed pregnant ferrets were obtained from Marshall Farms (North Rose, NY). Ferrets 4 months old or older were considered to be adults.

Antibodies. The regions in the trkB molecule recognized by the antibodies used in this study are schematically shown in Figure 1. Amino acid residue numbers are based on the mature trkB sequence. All trkB-specific antibodies are polyclonal and were prepared in rabbits. Anti-trkB ${ }_{23}$ and anti-trkB $B_{146}$ were generated against HPLC-purified synthetic peptides corresponding to amino acids 23-36 (AFPRLEPNSIDPENC) and 146163 (LNESSKNTPLANLQIPNC), respectively, in the extracellular domain of rat trkB, coupled to keyhole limpet hemocyanin via the $\mathrm{C}$-terminal cysteine residue. Both antisera were affinity-purified using the appropriate peptide coupled to Sulfo-Link gel (Pierce, Rockford, IL). Affinity-purified anti-trkBex was generated against a fusion protein of trpE linked to amino acids 37-341 in the extracellular domain of rat trkB, expressed in Escherichia coli. Pan-trk antibody, which recognizes the C terminus common to all members of the trk family, and anti-trkBout (Allendoerfer et al., 1994), prepared against amino acids 45-65 (QKRLEIINEDDVEAYVGLKNL) of rat trkB, were obtained from Dr. David Kaplan (Montreal Neurological Institute). Anti-trkB.T1, prepared against the 11 amino acid insert specific for the $\mathrm{T} 1$ truncated isoform of trkB, was obtained from Dr. Luis Parada (University of Texas Southwestern Medical School).

Cell lines. A full-length rat trkB cDNA was subcloned into the pBJ5 plasmid (Elliott et al., 1990). Twenty micrograms of the trkB plasmid were co-transfected with $2 \mu \mathrm{g}$ of pSVneo into NIH-3T3 fibroblasts with use of the calcium phosphate precipitation method (Wigler et al., 1979). Stable transfectants were selected by growth in $0.5 \mathrm{mg} / \mathrm{ml} \mathrm{G} 418$ (Geneticin; Life Technologies, Gaithersburg, MD). Individual colonies were isolated and trkB-expressing clones were identified by immunoblotting with anti-trkB 23 .

Western blotting. Ferret cortex was dissected at P15 or P55 and after removal of meninges was homogenized with a Polytron in $20 \mathrm{~mm}$ TrisHCL, pH 8.0, $150 \mathrm{~mm} \mathrm{NaCl}, 1 \%$ Triton X-100, $10 \%$ glycerol, $1 \mathrm{~mm}$ phenylmethylsulfonyl fluoride, and $1 \mathrm{mg} / \mathrm{ml}$ leupeptin (lysis buffer). After incubation for $30 \mathrm{~min}$ on ice to allow extraction of membrane proteins, homogenates were centrifuged at $12,000 \mathrm{rpm}$ for $10 \mathrm{~min}$, and the supernatants were removed and then resedimented for an additional $10 \mathrm{~min}$, yielding the solubilized extracts.

Enrichment for glycoproteins, by preadsorption to and elution from wheat germ agglutinin (WGA)-Sepharose $6 \mathrm{MB}$, has been used routinely to facilitate identification of trk proteins on immunoblots (Kaplan et al., 1991). Therefore, solubilized extracts were mixed with an equal or greater volume of $50 \%$ WGA-Sepharose slurry in lysis buffer, incubated overnight $(12-18 \mathrm{hr})$ at $4^{\circ} \mathrm{C}$ with shaking, and then washed three times with cold lysis buffer. Before electrophoresis, protein was eluted from the WGA-Sepharose by boiling for $5 \mathrm{~min}$ in sample buffer $(0.125 \mathrm{M}$ Tris- $\mathrm{HCl}$, $\mathrm{pH} 6.8,1 \%$ SDS, $2.5 \%$ glycerol, containing pyronin $\mathrm{Y}$ ) with $5 \%$ $\beta$-mercaptoethanol.

The peptide sequences $23-36$ and $146-163$ in trkB were chosen for antibody production based on their lack of sequence similarity to homologous regions in other members of the trk family; however, these two peptide sequences either contain or are adjacent to consensus glycosylation sites (Middlemas et al., 1991). To improve recognition of trkB on Western blots by these antibodies, additional cortical material was deglycosylated with recombinant PNGase F (New England Biolabs, Beverly, MA) according to the manufacturer's instructions. Cortical extracts were first incubated with a cocktail of pan-trk and anti-trkB.T1 antibodies ( $5 \mu 1$ each/100 $\mu$ l volume) to immunoprecipitate both full-length and T1 isoforms of trkB. The protein A-Sepharose pellets were resuspended in denaturing buffer $(0.5 \%$ SDS, $1 \% \beta$-mercaptoethanol) and incubated for $10 \mathrm{~min}$ at $100^{\circ} \mathrm{C}$. After sedimentation, the supernatants were brought to $1 \%$ in NP-40, PNGase F (5000 U) was added, and they were incubated at $37^{\circ}$ for $1 \mathrm{hr}$. The resulting material was diluted with an equal volume of $2 \times$ sample buffer and subjected to SDS-PAGE.

Solubilized extracts, WGA-treated extracts, and deglycosylated samples were resolved on an $8 \%$ acrylamide gel, transferred to nitrocellulose (Amersham, Arlington Heights, IL), and probed with antibodies as described in the text. Bands were visualized using enhanced chemiluminescence (Amersham).

Immunoprecipitation. Complexes of iodinated BDNF cross-linked to receptor proteins from P52 cortex were generated as described in Allendoerfer et al. (1994). Extracts solubilized with Triton X-100 were subjected to immunoprecipitation with pan-trk and anti-trkB.T1 antibodies followed by deglycosylation, essentially as described above. Immunoprecipitations with anti-trkB ${ }_{23}$ and anti-trkB ${ }_{146}$ were carried out on deglycosylated material in lysis buffer overnight at $4^{\circ} \mathrm{C}$. Immunoprecipitates were collected using protein A-Sepharose, washed four times with lysis buffer, and analyzed by SDS-PAGE followed by autoradiography.

Immunohistochemistry. Ferrets, ages E30 to adult, were perfused trans- 

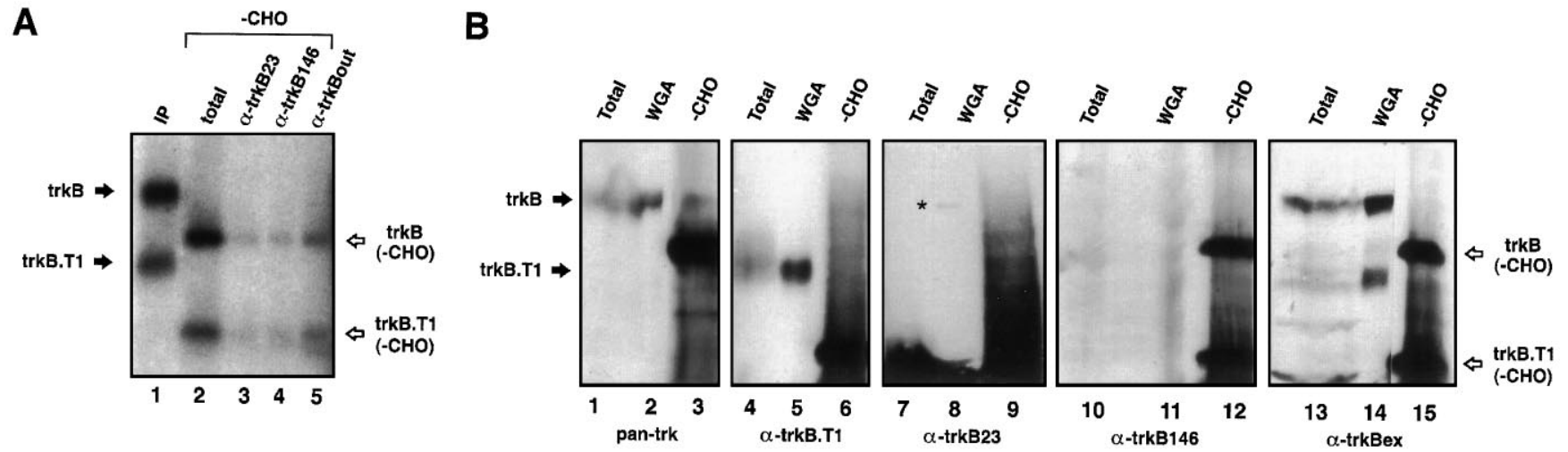

Figure 2. Analysis of anti-trkB $\mathrm{B}_{23}$ and anti-trkB ${ }_{146}$ specificity in immunoblot and immunoprecipitation assays. $A$, Iodinated BDNF was cross-linked to receptors in suspensions of freshly dissected P15 ferret cortex. BDNF-trkB complexes were immunoprecipitated with pan-trk and anti-trkB.T1 (IP), followed by deglycosylation with PNGase F (-CHO, Total). Equal amounts of sample were immunoprecipitated with either anti-trkB ${ }_{23}(9 \mu \mathrm{g} / \mathrm{ml})$, anti-trkB $_{146}(5 \mu \mathrm{g} / \mathrm{ml})$, or anti-trkBout (1:100). Immunoprecipitates were visualized by autoradiography of SDS-PAGE gels. $B$, Solubilized extracts (Total), material enriched for glycoproteins by adsorption to wheat germ agglutinin-Sepharose (WGA), and deglycosylated samples (-CHO) were prepared from P30 ferret cortex as described in Materials and Methods. Immunoblots of these fractions were probed with pan-trk (1:1500), anti-trkB.T1 (1:1500), anti-trkB ${ }_{146}(2 \mu \mathrm{g} / \mathrm{ml})$, anti-trkB $23(2 \mu \mathrm{g} / \mathrm{ml})$, and anti-trkB ${ }_{\text {ex }}(2.5 \mu \mathrm{g} / \mathrm{ml})$.

cardially with $0.1 \mathrm{M}$ sodium phosphate buffer, $\mathrm{pH} 7.35$, followed by freshly prepared $4 \%$ paraformaldehyde in the same buffer. Brains were removed, equilibrated in $25 \%$ or $30 \%$ sucrose, and then embedded in gelatinalbumin. Sections ( $25 \mu \mathrm{m}$ thick) were cut on a freezing microtome and were stored in $2 \%$ paraformaldehyde until needed.

Immunostaining on free-floating sections was performed as follows. Sections were washed $3 \times 5 \mathrm{~min}$ with PBS, followed by a $1 \mathrm{hr}$ blocking step at room temperature in PBS, $0.5 \%$ BSA, $0.1 \%$ Triton $\mathrm{X}-100$ or Tween 20 (Sigma, St. Louis, MO). (Tween was found to be superior to Triton in reducing background staining in tissue from the older $(>\mathrm{P} 10)$ animals, and it was used in staining sections from animals $\geq$ P5 unless indicated otherwise.) Primary antibody was added in the same blocking solution at concentrations ranging from 0.25 to $2 \mathrm{mg} / \mathrm{ml}$. Optimal primary antibody concentration was determined empirically for each age studied. Incubation with primary antibody was carried out overnight (12-18 hr) at $4^{\circ} \mathrm{C}$ with gentle shaking. Sections were washed with blocking solution at room temperature for $3 \times 5 \mathrm{~min}$ followed by a a single $1 \mathrm{hr}$ wash. Incubation with biotinylated goat anti-rabbit secondary antibody was also overnight at $4^{\circ} \mathrm{C}$ and was followed by washing with PBS for $3 \times 5 \mathrm{~min}$ and $1 \times 1 \mathrm{hr}$. Bound secondary antibody was visualized with the Vectastain Elite ABC immunoperoxidase system (Vector Labs, Burlingame, CA), using diaminobenzidine as the chromogen.

For immunocytochemistry, cell lines were plated on 4-well permanox Lab-Tek slides (Nunc, Naperville, IL) at a density of $2 \times 10^{6} \mathrm{cells} / \mathrm{cm}^{2}$. Cells were washed in $0.1 \mathrm{~m}$ sodium phosphate, $\mathrm{pH} 7.35$, and then fixed in $4 \%$ paraformaldehyde in the same buffer. Immunostaining was performed essentially as described above, except that incubation times were shortened to $1 \mathrm{hr}$ for the primary and secondary antibodies. To minimize loss of cells during the initial fixation and subsequent washings, cells were washed by repeated $(8 \times)$ replacements of half the well volume.

TrkB peptides $23-36$ and 146-163 were used in blocking experiments to assess antibody specificity. The peptides were initially resuspended and stored in dimethylsulfoxide (DMSO) at $15 \mathrm{mg} / \mathrm{ml}$. For blocking experiments, the primary antibody was diluted in blocking buffer and preincubated with $50 \mathrm{mg} / \mathrm{ml}$ (or greater, as in Fig. 3) of peptide for 1-3 hr at room temperature before incubation with tissue sections. Each primary antibody was preincubated with the peptide to which it was made, and also with the heterologous peptide or DMSO $(0.33 \%)$ alone as controls.

\section{RESULTS}

We have characterized the developmental expression of trkB in the mammalian visual system and cerebral cortex at the cellular level using two affinity-purified anti-peptide antibodies (anti$\operatorname{trkB}_{23}$ and anti-trkB $B_{146}$ ) directed against epitopes within the extracellular domain of trkB. The results are presented in two sections. First, to validate the use of these antibodies, tests of their specificity were carried out using biochemical, immunocytochem- ical, and immunohistochemical assays. Next, we present a description of the changes in the pattern of trkB immunohistochemical staining in the developing visual system.

\section{Specificity of anti-trkB ${ }_{23}$ and anti-trkB 146}

The ability of both antibodies to immunoprecipitate trkB protein in solution was tested using as a substrate trkB covalently crosslinked to iodinated BDNF. At least two forms of trkB are present within the CNS, as a result of alternative mRNA splicing (Klein et al., 1990a). First, there is a full-length receptor molecule (designated as "trkB.FL") possessing $\sim 400$ cytoplasmic amino acids, including a tyrosine kinase signaling domain. Second, there is a "truncated" receptor (designated as "trkB.T1") possessing the identical extracellular and transmembrane domains as the fulllength polypeptide but only 23 well conserved cytoplasmic amino acids with an as yet unknown function. Complexes of iodinated BDNF cross-linked to full-length trkB and to trkB.T1 from ferret cortex (Allendoerfer et al., 1994) are shown in Figure $2 A$, before (lane 1) and after (lane 2) enzymatic removal of carbohydrate by PNGase. Both anti-trkB ${ }_{23}$ and anti-trkB ${ }_{146}$ were able to immunoprecipitate the trkB-BDNF and trkB.T1-BDNF complexes after denaturation and deglycosylation, as demonstrated in lanes 3 and 4 , but were unable to immunoprecipitate native trkB-BDNF complexes (data not shown). This inability may relate to the presence of consensus $N$-linked glycosylation sites within or adjacent to the sequences chosen for the peptide immunogens. These antibodies did not immunoprecipitate NT-3-trkC complexes under any conditions (data not shown), indicating that they are specific for trkB relative to trkC.

Similar results were obtained regarding recognition by these antibodies of trkB on immunoblots (Fig. 2B). Blots of detergentsolubilized extracts, extracts enriched for glycoproteins by adsorption to WGA-Sepharose, and fully deglycosylated extracts of ferret cortex were probed with pan-trk, anti-trkB.T1, anti-trkB ${ }_{23}$, anti-trkB $\mathrm{B}_{146}$, and for comparison, anti-trkB $\mathrm{B}_{\mathrm{ex}}$, an antibody generated against the extracellular domain of trkB that has been shown to recognize purified trkB extracellular domain in immunoblots (A. Welcher, data not shown). Blots probed with pan-trk (lanes 1-3) show major bands corresponding to intact and deglycosylated full-length trk molecules, whereas probing the blots with anti- 

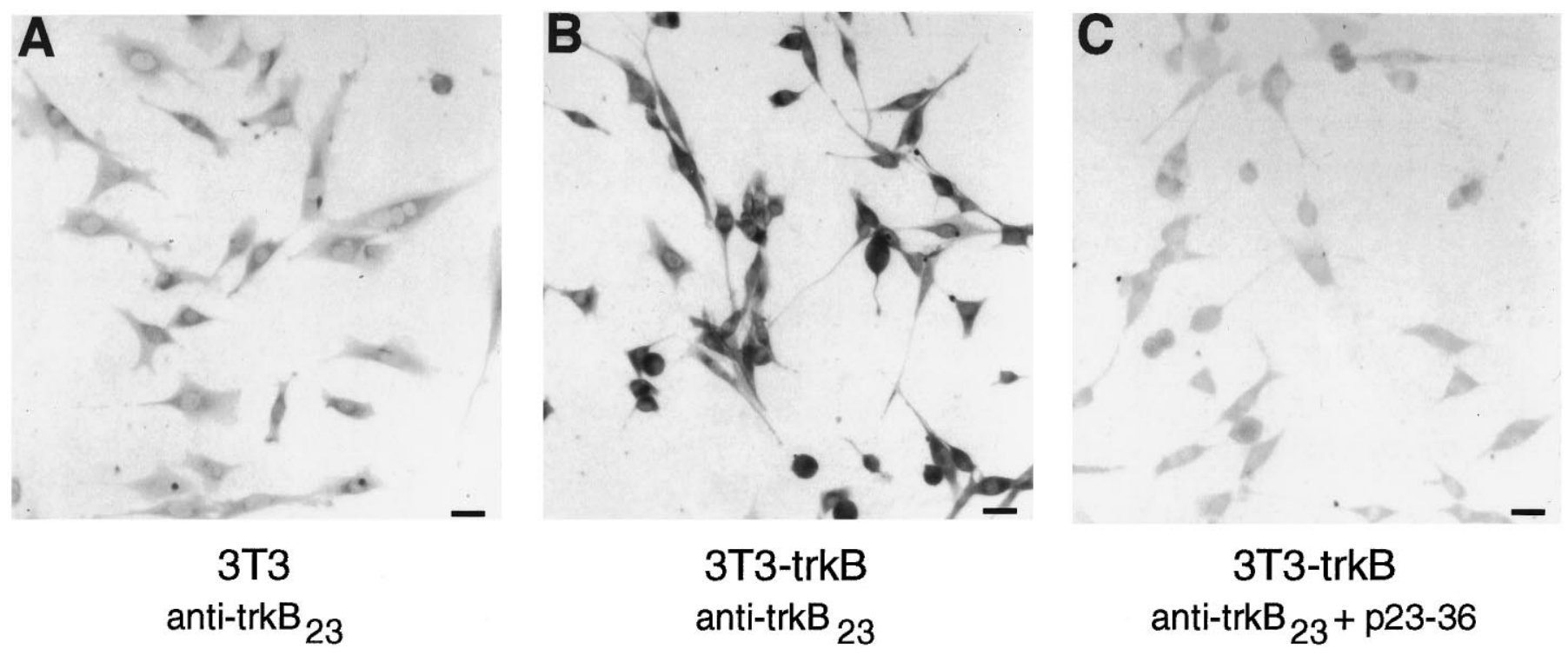

Figure 3. Staining of $3 \mathrm{~T} 3$ cells with anti-trkB ${ }_{23}$ : dependence on expression of $\operatorname{trkB}$ and prevention by preincubation with the immunizing peptide. $3 \mathrm{~T} 3$ cells $(A)$ and 3 T3 cells transfected with a trkB-expressing plasmid $(B, C)$ were stained with anti-trkB ${ }_{23}(2.5 \mu \mathrm{g} / \mathrm{ml})$. In $C$, staining was performed after preincubation of anti-trkB $23(2.5 \mu \mathrm{g} / \mathrm{ml})$ with peptide $23-36(100 \mu \mathrm{g} / \mathrm{ml})$. Scale bar, $50 \mu \mathrm{m}$.

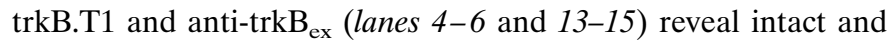
deglycosylated full-length trkB and trkB.T1. Enrichment for glycoproteins by preadsorption to WGA-Sepharose generally reduces the number of background bands seen by these antibodies. Faint bands corresponding in size to full-length trkB and trkB.T1 were sometimes observed in blots of WGA-enriched material probed with anti-trkB ${ }_{23}$ and anti-trkB ${ }_{146}$ (for example, Fig. $2 B$, lane 8 ). Deglycosylation greatly increased the recognition of trkB on immunoblots by anti-trkB ${ }_{23}$ and particularly anti-trkB ${ }_{146}$ (Fig. $2 B$, lane 12). Although the trkB-specific antibodies are all able to recognize bands corresponding to full-length trkB or full-length deglycosylated trkB, in this and other experiments they exhibit different patterns of labeling of non-trk bands, suggesting that their common pattern of staining (see below) is a consequence of their shared recognition of trkB. Similar observations have been made in the analysis of rat brain preparations with these antibodies (M. Radeke and S. Feinstein, unpublished observations), indicating that the modest recognition of glycosylated trkB by these antibodies is not a result of differences between rat and ferret trkB. Rather, our observations likely reflect both partial masking of these epitopes by glycosylation and the low abundance of trkB relative to other proteins in these extracts. Thus, anti-trkB $\mathrm{B}_{23}$ and anti-trkB ${ }_{146}$ strongly recognize trkB in immunoblots of NIH-3T3 cells that overexpress trkB (M. Radeke and S. Feinstein, unpublished observations).

To determine whether anti-trkB ${ }_{23}$ and anti-trkB ${ }_{146}$ are able to recognize specifically trkB in situ on cells, immunocytochemistry was carried out on NIH-3T3 cells (which do not normally express trkB) and NIH-3T3 cells transfected with a plasmid encoding rat trkB.FL. Staining with anti-trkB $B_{23}$ is dramatically increased in the trkB-expressing cells (Fig. $3 B$ ) when compared with untransfected 3 T3 cells (Fig. $3 A$ ). Moreover, this trkB-dependent staining can be blocked by preincubation of the antibody with the peptide against which it was made (Fig. 3C). This suggests that the immunostaining blocked by preincubation with peptide is specific for trkB. Similar results were obtained with anti-trkB ${ }_{146}$ (data not shown). In addition, 3T3 cells expressing trkA did not show staining with either antibody (data not shown), indicating that both antibodies specifically recognize trkB, but not trkA, in immunocytochemistry.

We next directly addressed the utility of these antibodies in immunohistochemistry of ferret brain sections. Messenger RNA for trkB (but not trkA) has been observed in the pyramidal neurons and the dentate gyrus of the adult hippocampus (Klein et al., 1990a). Furthermore, neurons within the hippocampus have been observed to transport iodinated BDNF retrogradely (DiStefano et al., 1992). Thus, this structure would be expected to express trkB protein. Accordingly, tissue sections from adult ferret cortex containing hippocampus were stained with anti-trkB ${ }_{23}$ and anti-trkB ${ }_{146}$. As shown in Figure 4, neurons in the dentate gyrus and pyramidal cells in the CA1 and CA3 areas of the hippocampus indeed stain with both anti-trkB ${ }_{23}$ (Fig. $4 A$ ) and anti-trkB $_{146}$ (Fig. $4 B$ ).

To investigate further the specificity of immunostaining with these antibodies, the patterns of staining of ferret cortex by anti-trkB ${ }_{23}$ and anti-trkB ${ }_{146}$ were compared with each other and with anti-trkB $B_{\text {ex }}$ at several different ages (Fig. 5). All three affinitypurified antibodies recognize fiber tracts in the intermediate zone (IZ) at prenatal ages (Fig. $5 A-C$ ), subplate neurons during early postnatal cortical development (Fig. $5 D-F$ ), and particular subsets of cortical neurons-in particular large pyramidal neurons in layers 3 and 5-later in development (Fig. 5G-I). (These staining patterns will be described in more detail below.) That these three antibodies, which were generated against different parts of the trkB molecule, exhibit an identical and highly restricted pattern of immunostaining across cortical [and subcortical (not shown)]) CNS development makes it extremely likely that the observed staining pattern reflects specific recognition of trkB.

An additional test of antibody specificity is whether the staining in tissues can be blocked by preincubation of the antibody with the peptide against which it was made, as had been shown in 3T3 cells expressing trkB (Fig. 3). The results of two such peptide blocking experiments are shown in Figure 6. Preincubation of anti-trkB $B_{23}$ with excess homologous peptide (23-36), but not heterologous peptide (146-163), blocks all staining of cortical fiber tracts at E30 

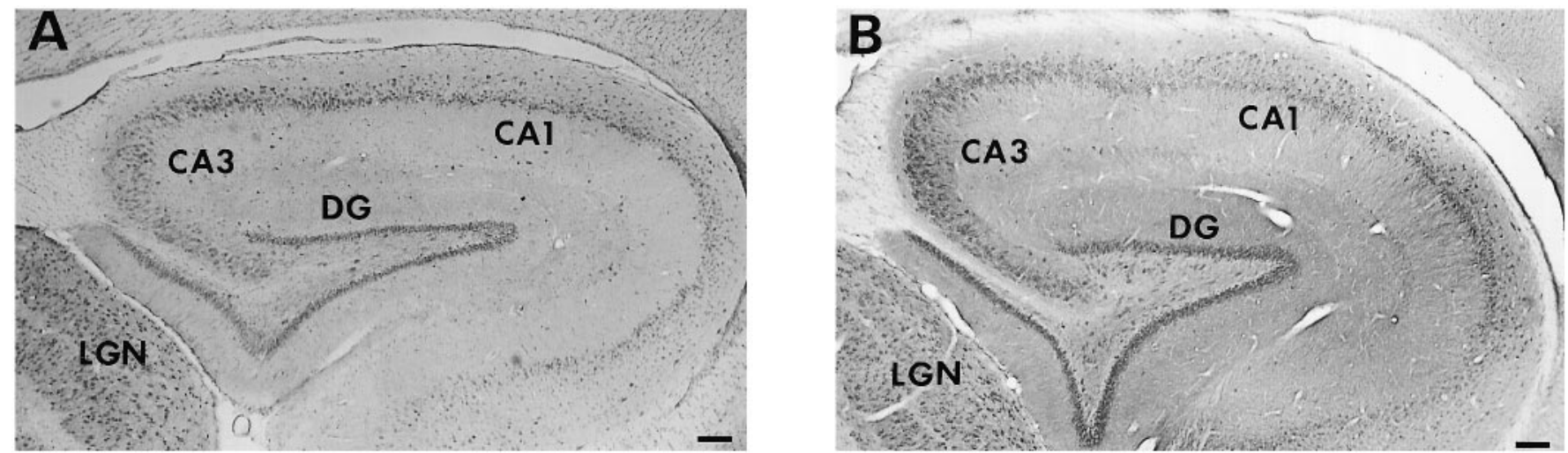

Figure 4. Distribution of trkB-immunoreactive cells in the adult hippocampus. Sagittal sections containing adult ferret hippocampus were stained with anti-trkB ${ }_{23}, 2 \mathrm{mg} / \mathrm{ml}(A)$, or anti-trkB ${ }_{146}, 2 \mathrm{mg} / \mathrm{ml}(B) . D G$, Dentate gyrus; $L G N$, lateral geniculate nucleus. Scale bar, $160 \mu \mathrm{m}$.

(Fig. 6A-C). Similarly, preincubation of anti-trkB 146 with homologous but not heterologous peptide also abolishes all specific cellular staining at P10 (Fig. 6D-F). This same specificity of peptide blocking was observed at all ages with both antibodies (not shown). Taken together, (1) the common pattern of immunostaining by three different antibodies, (2) the ability of these antibodies to stain specifically cell lines expressing trkB, (3) the fact that the immunostaining in both cell lines and tissues is blocked by the particular peptides against which these antibodies were prepared, and finally, (4) the demonstration that these antibodies recognize trkB on immunoblots and by immunoprecipitation in solution strongly suggest that the immunohistochemistry presented above and in succeeding figures represents staining for trkB protein.

\section{TrkB protein expression during visual system development}

TrkB expression was analyzed by immunohistochemistry throughout ferret visual system development, from E30 through adulthood. The results obtained in these studies are divided into three sections that describe expression (1) in neurons in the cerebral cortex with emphasis on visual cortex, (2) in developing and mature glia, and (3) in other subcortical visual structures.

\section{TrkB expression in the cerebral cortex}

\section{Early pattern}

At the earliest ages studied, E30 and E38, the cerebral wall consists of the ventricular zone (VZ), IZ, cortical plate (CP), and marginal zone (MZ) (Fig. 7C). The CP has not yet fully formed; cortical neurogenesis is ongoing at these ages in the VZ, and only neurons of the deep cortical layers (5 and 6) have completed their migrations by E38 (Jackson et al., 1989). Ascending (corticopetal) and descending (corticofugal) fiber tracts are being established in the IZ (the future white matter). Cortical trkB immunostaining is primarily confined to these fiber tracts and is presumably axonal in nature, as shown in Figure $7 A, B, D$ (also see Fig. $5 A-C$ ). Some of these fibers appear to traverse the internal capsule and then fan out into the $\mathrm{CP}$ and thalamus, as expected for the ascending and descending axon fiber tracts (Fig. 7A). At E38, two distinct fiber tracts are observed, one located in the upper part of the IZ (i.e., the subplate region) and one located just above the VZ (Fig. $7 B-D)$. A similar pattern of immunostaining was observed at $\mathrm{P} 2$, although some cellular staining is now also apparent in the VZ, subplate, and CP (data not shown). In addition, there is dense fiber staining in the MZ, which is known to contain several axonal projection systems at these early ages (Fig. 7D).

\section{Intermediate stage}

By P5, cortical neurogenesis has ended and the only remaining germinal zone is the subventricular zone (SVZ) (Fig. 8A), which is thought to be the site of generation of glial cells; however, the migration of cells to layers 2 and 3 is far from complete (Jackson et al., 1989). Thalamocortical axons have left the subplate and have begun to invade their final targets in layer 4. In turn, descending axons from layers 5 and 6 are also innervating their targets in the thalamus and tectum (McConnell et al., 1994). At P5, the cell bodies and dendrites of subplate neurons are heavily trkB immunoreactive, whereas the fiber tracts seen prenatally remain stained, although less strongly (Fig. 8A). By P10, the fiber tract staining has largely disappeared, and layer 5 pyramidal neurons are now stained in addition to subplate neurons (Fig. $8 B, C)$. Cells and processes emanating from the $\mathrm{SVZ}$ are also trkB immunoreactive (see below). A similar pattern of subplate and layer 5 cellular staining is seen all along the anterior-posterior axis within the developing cortex (Fig. $8 D$ ), although the relative intensities of staining in the two cell populations does vary between different cortical areas.

By P24, cell migration is complete, and the cortex has achieved its adult pattern of lamination. Staining of layer 5 neurons, particularly the large pyramidal cells, is still apparent in many cortical areas, including sensorimotor (Fig. $8 E$ ) and visual (Fig. $8 F$ ) cortex; however, far fewer subplate neurons continue to stain for trkB, and those that do are primarily in posterior cortical areas, especially visual cortex (compare Fig. 8, $G$ and $H$ ), as determined by both morphological and birth-dating analysis (see below). Some layer $2 / 3$ neurons are now stained for trkB, and astrocytes are strongly trkB immunoreactive throughout the $\mathrm{CP}$ and IZ (Figs. $8 E-G, 11$ ).

To confirm that the stained cells in the subplate are indeed subplate neurons, ${ }^{3} \mathrm{H}$-thymidine labeling was performed at E24, a date when predominantly subplate neurons, and very few $\mathrm{CP}$ neurons, are being generated in ferret (Jackson et al., 1989). Brains were then immunostained for trkB at P10 (Fig. 9A,B), almost four weeks after the injection of ${ }^{3} \mathrm{H}$-thymidine, and at other postnatal ages (not shown). The ${ }^{3} \mathrm{H}$-thymidine labeling, together with the inverted pyramidal morphology of some of the stained cells, confirms the identity of the trkB-immunoreactive cells in the subplate as subplate neurons (Chun and Shatz, 1989). 


\section{E38 Cortex}
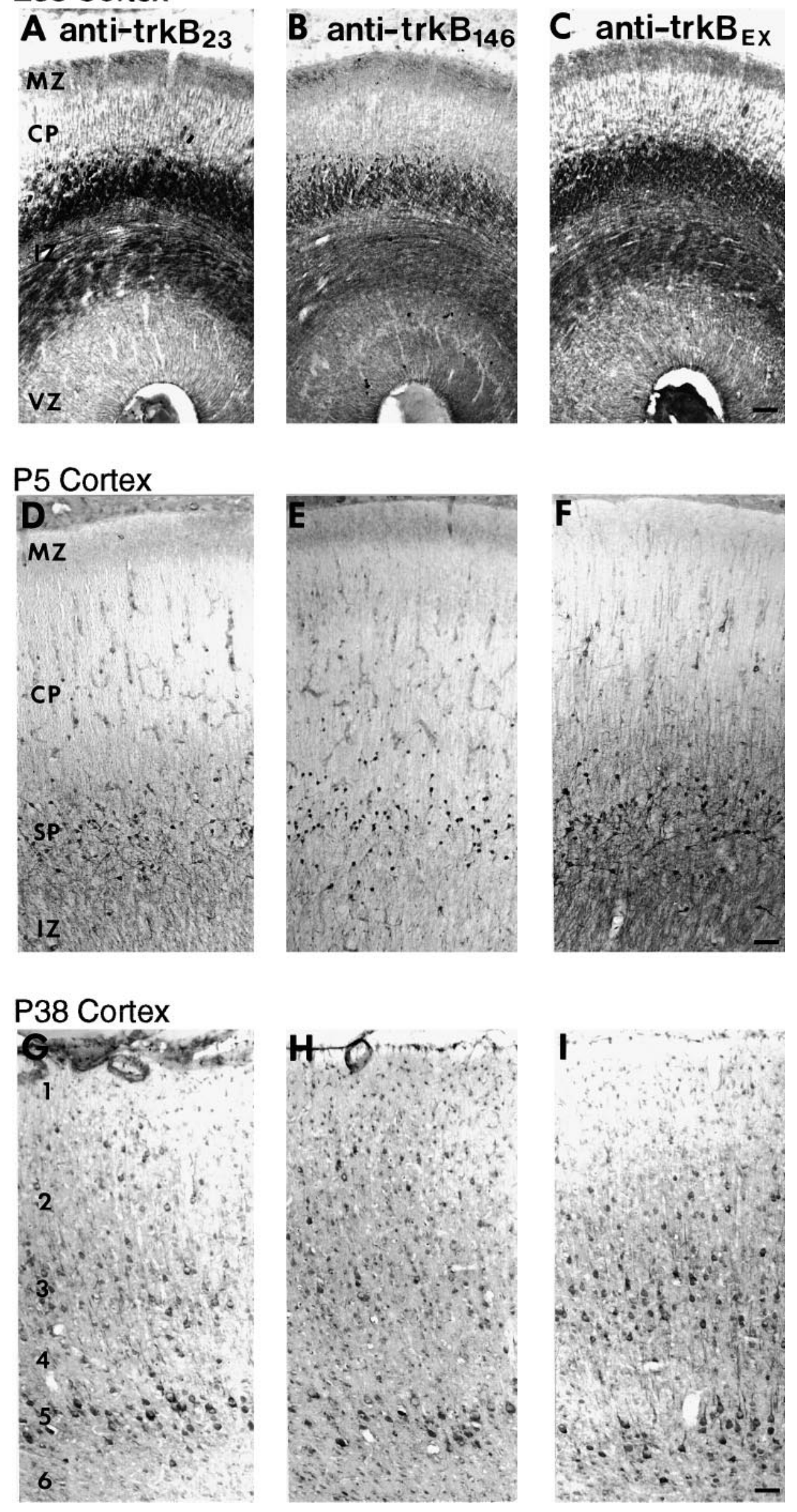

Figure 5. Comparison of cortical distribution of trkB-immunoreactive cells and fibers using three distinct anti-trkB antibodies over a wide range of developmental ages. $A-C$, Coronal sections from an E38 ferret stained with $0.5 \mu \mathrm{g} / \mathrm{ml}$ anti-trkB ${ }_{23}$ (A), $1 \mu \mathrm{g} / \mathrm{ml}$ anti-trkB ${ }_{146}(B)$, or $2.8 \mu \mathrm{g} / \mathrm{ml}$ antitrkB $_{\text {ex }}(C) . D-F$, Sagittal sections from a P5 ferret stained with $0.5 \mu \mathrm{g} / \mathrm{ml}$ anti-trkB ${ }_{23}(D), 2 \mu \mathrm{g} / \mathrm{ml}$ anti-trkB $_{146}(E)$, or $2.8 \mu \mathrm{g} / \mathrm{ml}$ anti-trkB ex $(F)$. $G-I$, Sagittal sections from a P38 ferret stained with 1 $\mu \mathrm{g} / \mathrm{ml}$ anti-trkB ${ }_{23}(G), 2 \mu \mathrm{g} / \mathrm{ml}$ anti-trkB ${ }_{146}(H)$, or $1.4 \mu \mathrm{g} / \mathrm{ml}$ anti-trkB ${ }_{\text {ex }}(I) . C P$, Cortical plate; $I Z$, intermediate zone; $M Z$, marginal zone; $S P$, subplate; $V Z$, ventricular zone; 1 , cortical layer $1 ; 2$, layer 2 ; 3 , layer $3 ; 4$, layer $4 ; 5$, layer $5 ; 6$, layer 6 . Scale bars: $A-C, 55 \mu \mathrm{m} ; D-F, 55 \mu \mathrm{m} ; G-I, 55 \mu \mathrm{m}$. 


\section{E30 Cortex}

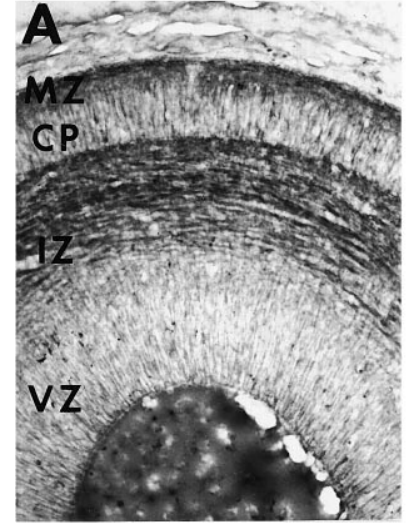

anti-trkB 23

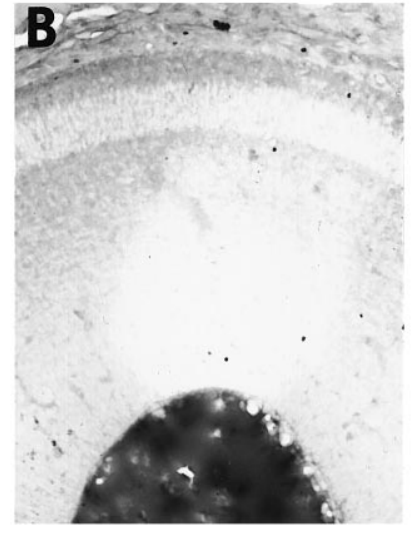

anti-trkB $23+$ p23-36

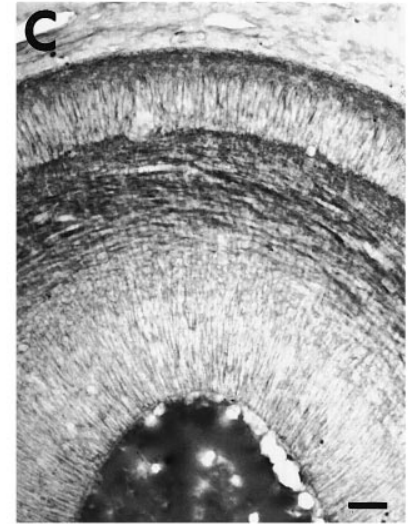

anti-trkB ${ }_{23}+$ p146-163

\section{P10 Cortex}

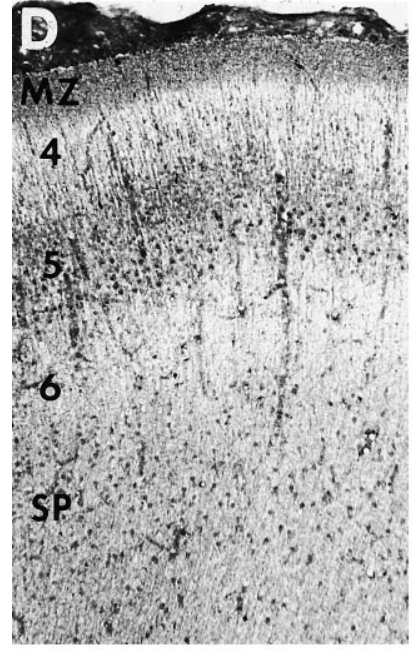

anti-trkB 146

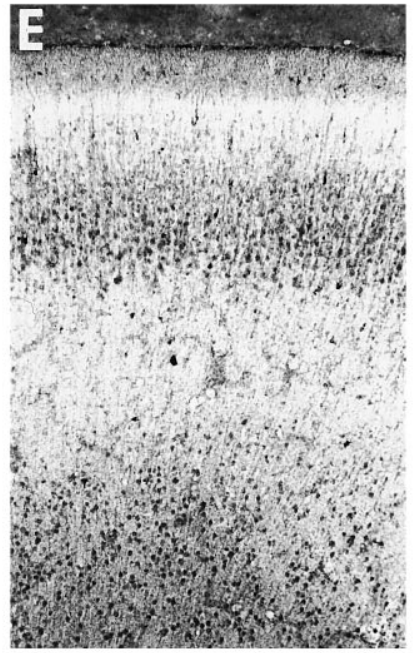

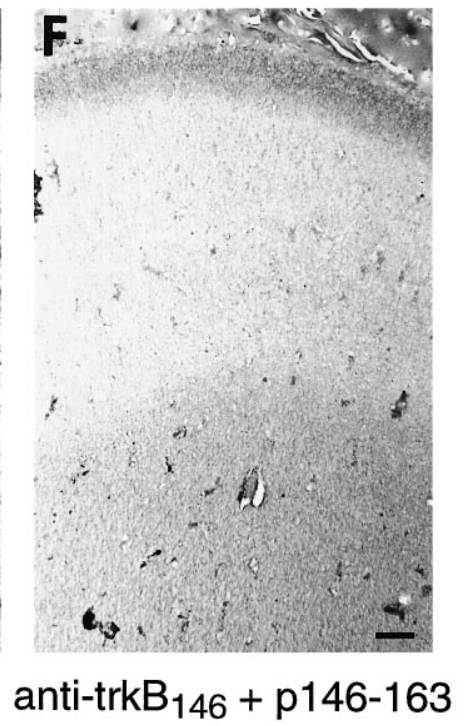

Figure 6. Effects of preincubation of anti-trkB $B_{23}$ and anti-trkB ${ }_{146}$ with $\operatorname{cog}$ nate or heterologous peptide on the pattern of immunohistochemical staining. Adjacent E30 horizontal sections were stained with anti-trkB ${ }_{23}(1 \mu \mathrm{g} / \mathrm{ml})$ after preincubation with either buffer $(A)$ peptide 23-36 (B), or peptide 146-163 $(C)$. Adjacent P10 sagittal sections were stained with anti-trkB ${ }_{146}(1 \mu \mathrm{g} / \mathrm{ml})$ after preincubation with either buffer $(D)$, peptide 23-36 (E), or peptide 146-163 $(F)$. Abbreviations as in Figure 5. Scale bars: $A-C, 50 \mu \mathrm{m} ; D-F, 65 \mu \mathrm{m}$.
Because ${ }^{3} \mathrm{H}$-thymidine is only available for uptake for $\sim 4 \mathrm{hr}$ after injection (Hickey et al., 1983), and the entire population requires almost 1 week to be generated, a single pulse injection of ${ }^{3} \mathrm{H}$ thymidine will label only a fraction of subplate neurons. Thus, not all trkB-immunoreactive subplate neurons are ${ }^{3} \mathrm{H}$-thymidinelabeled. On the other hand, it is also clear that not all ${ }^{3} \mathrm{H}-$ thymidine-labeled neurons are trkB immunoreactive (Fig. 9A,B). Those subplate neurons that are not immunoreactive for trkB might express other members of the trk family, other growth factor receptors, or no growth factor receptors at all; for example, subplate neurons have been shown to express p75, the low-affinity neurotrophin receptor, during early postnatal life in the ferret (Allendoerfer et al., 1990). On examination at higher magnification, it can be seen that trkB is associated with both the cell soma and dendrites of subplate neurons (Fig. 9B,C). In addition, varicosities along the length of processes are clearly stained (Fig. 9C).

\section{Adult pattern}

Between P18-24 (or developmentally comparable ages in the cat) and adulthood, the majority of subplate neurons die (ferret: A.
Hohn, A. Raymond, K. L. Allendoerfer, and C. J. Shatz, unpublished observations; cat: Chun and Shatz, 1989), and thalamic inputs to cortical layer 4 of visual cortex segregate to form OD columns (ferret: E. Finney and C. J. Shatz, unpublished observations; cat: Levay et al., 1978). By P31, trkB immunostaining is present primarily in pyramidal neurons in cortical layers 3 and 5 . As shown at P38, this pattern is especially apparent in sensorimotor cortex (Fig. 10B), where very few trkB-immunoreactive layer 4 neurons are observed, despite the high cell density of this layer (compare Fig. 10, $C$ and $D$ ). In visual cortex, this particular laminar pattern of staining is slightly less distinct, although stained layer 5 and layer 3 neurons are seen as well as the occasional layer 4 neuron (Fig. 10A,B). By $\mathrm{P} 45$, the distribution of neuronal trkB immunoreactivity had spread to include neurons in all cortical layers (Fig. 10E). As seen at earlier ages, stained neurons are predominantly pyramidal in morphology. This pattern is maintained at P66 (data not shown) and in the adult (Fig. 10F, G).

On examination of layer 5 pyramidal neurons at higher magnification (Fig. $10 H$ ), it can be seen that the rims of many neurons 

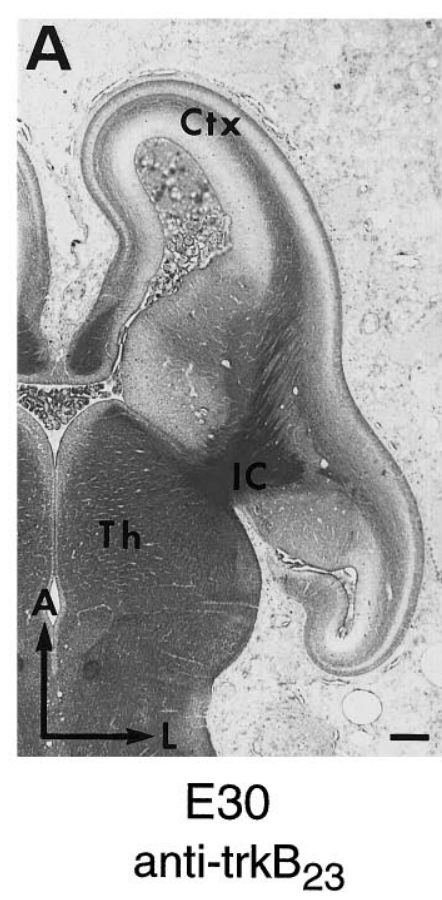

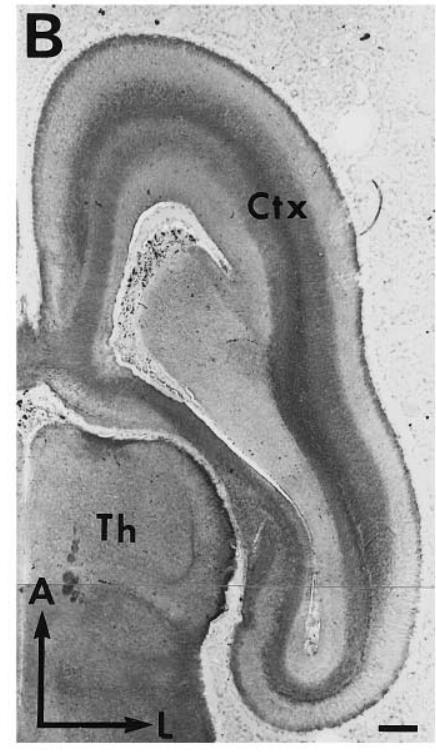

E38 anti-trkB 23
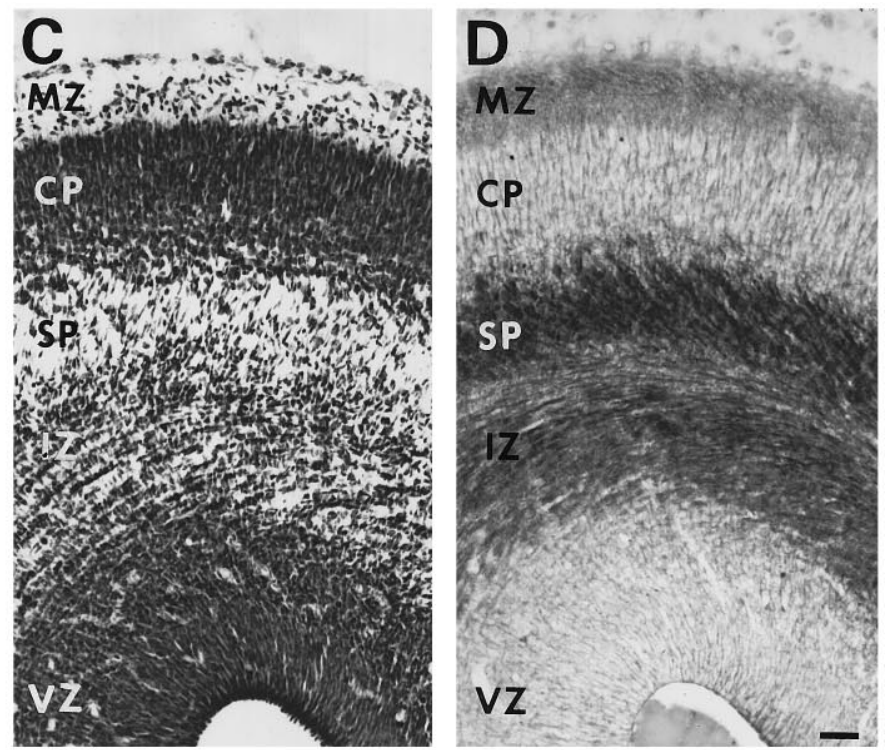

E38 Cortex

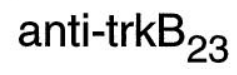

Figure 7. Distribution of trkB immunoreactivity within the cortex during prenatal development. $A$, Horizontal section from an E30 ferret stained with $0.5 \mu \mathrm{g} / \mathrm{ml}$ anti-trkB ${ }_{23} . B$, Horizontal section from an $\mathrm{E} 38$ ferret stained with $0.5 \mu \mathrm{g} / \mathrm{ml}$ anti-trkB ${ }_{23}$. $C, D$, Adjacent coronal sections from an E38 ferret stained with cresyl violet $(C)$ or $0.5 \mu \mathrm{g} / \mathrm{ml}$ anti-trkB ${ }_{23}(D)$. Medial cortex is shown at the level of the thalamus in the rostral-caudal axis. $A$, Anterior; $C t x$, cortex; $I C$, internal capsule; $L$, lateral; Th, thalamus. Other abbreviations as in Figure 5. Scale bars: $A, 265 \mu \mathrm{m} ; B, 320 \mu \mathrm{m} ; C, D, 36 \mu \mathrm{m}$.

are stained, suggestive of cell membrane localization. In addition, trkB is present on both apical and basal dendrites.

\section{TrkB in cortical glia}

From E30 through P2, radially oriented fibers extending upward from the VZ stain for trkB (Fig. 7D). Later in development, from P5 through P24, cell bodies in the SVZ, the site of generation of glial precursors, and fibers emanating from it are also trkB immunoreactive (Figs $8 A-D, 11 A$ ). The morphology of these fibers and the location of the stained cell bodies associated with them (Fig. 11 $A$ ) suggested that they might correspond to radial glial cells, which are known to have cell bodies situated within and above the SVZ and to extend fibers radially up to the CP (Schmechel and Rakic, 1979; Voigt, 1989; Edwards et al., 1990). To examine this possibility, sections from P10 ferret were doublestained with anti-trkB ${ }_{146}$ and antibody to vimentin, an intermediate filament protein expressed in radial glial fibers early in development (Engel and Müller, 1989; Voigt, 1989). This doublestaining reveals that trkB-immunoreactive fibers (Fig. 11B) are also immunoreactive for vimentin (Fig. 11C,D), demonstrating that these trkB-immunoreactive fibers and associated cell bodies correspond to radial glia. The staining with anti-trkB ${ }_{146}$ of both the radial glia cell bodies and fibers and of other cells in the SVZ was blocked by an excess of peptide ${ }_{146-164}$ (data not shown).

Later, at P24, large numbers of trkB-immunoreactive cells with astrocytic morphology are present throughout the gray and white matter (Figs. 8E-H, 11E). The appearance of this population of trkB-immunoreactive cells correlates with the decline in vimentinpositive radial glia and the appearance of astrocytes in the ferret cerebral wall as revealed by GFAP staining (Voigt, 1989). The intensity of astrocyte staining for trkB declines with subsequent development (Fig. 10 and data not shown).

\section{TrkB expression in the LGN and other subcortical visual structures}

At E30 and especially at E38, trkB-immunoreactive fibers are visible in and around the LGN (the major target of RGC axons), just as in the cortex at these early ages. The staining is located chiefly within the optic tract and other fiber-containing regions (Figs. $7 B, 12 A, B$ ). Within the LGN, trkB-immunoreactive fibers are clustered superficially (Fig. 12A,B), in the optic tract and in the regions into which RGC axons have grown (Shatz, 1983; Cucchiaro and Guillery, 1984). Although it is possible that intrathalamic fibers or brainstem inputs to the thalamus may also contribute to the fiber staining within the LGN, it is unlikely that corticothalamic fibers contribute to this fiber staining at this early age. In view of the reported survival effect of BDNF on RGCs during development (Johnson et al., 1986; Rodriguez-Tébar et al., 1989), we suggest that trkB may be localized to RGC terminals within these structures at these times. Moreover, the presence of trkB on select RGCs and on axon bundles leaving the mammalian retina has been demonstrated recently by us (R. Cabelli and C. J. Shatz, unpublished observations) and others (Rickman and Brecha, 1995) during development and in the adult (Jelsma et al., 1993; G. Lewis, M. Radeke, S. Fisher, and S. Feinstein, personal communication).

By $\mathrm{P} 5$, as in the $\mathrm{CP}$, fiber staining for trkB has begun to decline in intensity and is replaced by cellular staining in neurons located in the region of the future C-layers (Fig. 12C). Intense trkB immunoreactivity at P10 (data not shown) and P24 (Fig. 12D,E) seemed to be confined primarily to the C-layers of the LGN and to the perigeniculate nucleus (PGN); only very lightly stained neurons are seen in the A-layers. The PGN is an area just outside the LGN that like the subplate contains neurons that are generated very early (Mitrofanis, 


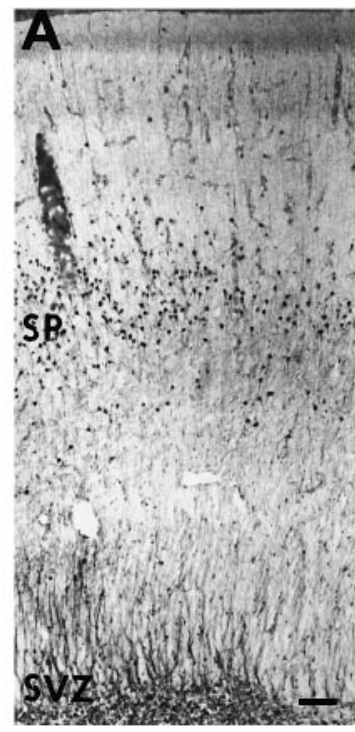

P5 anti-trkB 146

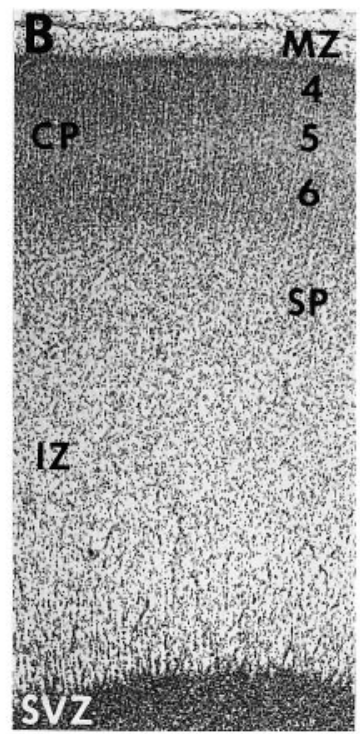

P10 cresyl violet / anti-trkB146

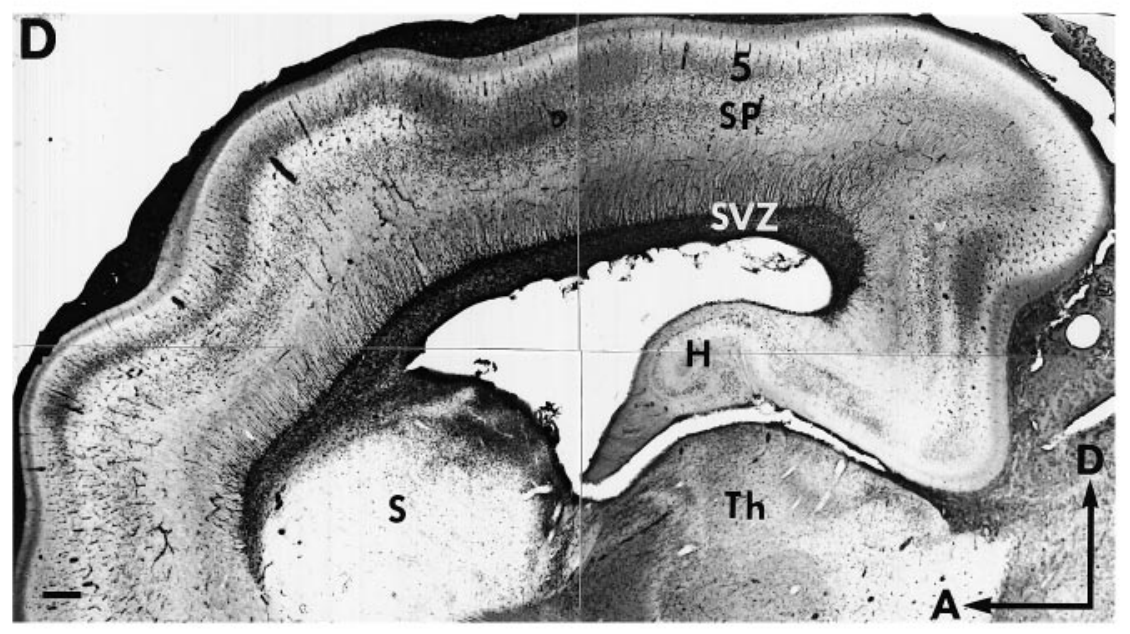

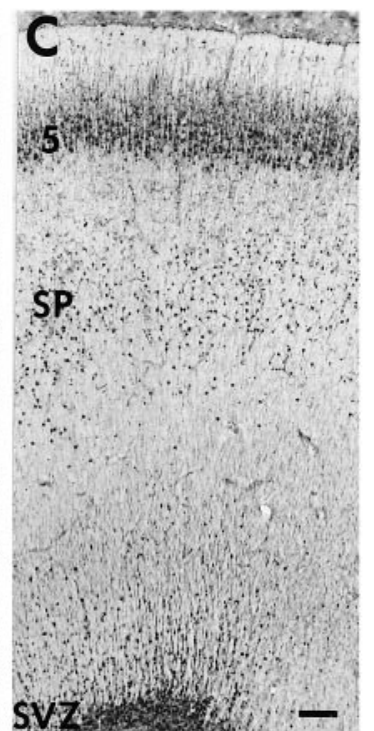
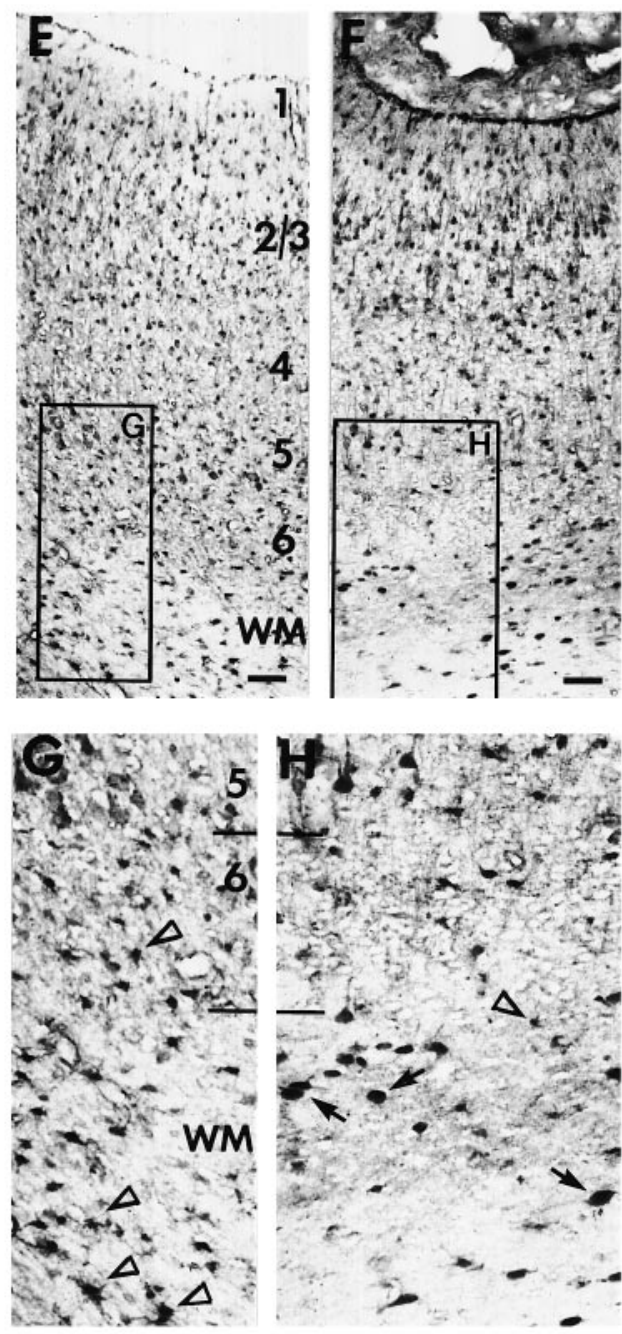

sensorimotor

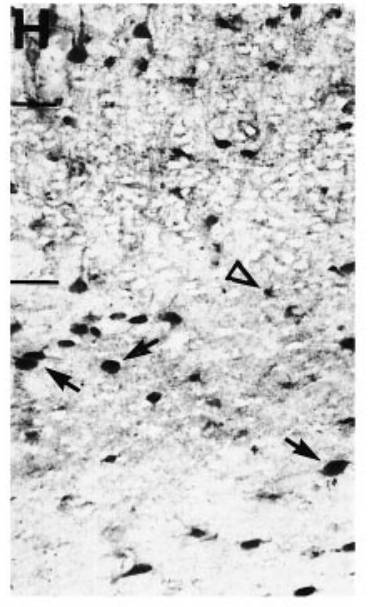

visual

P24 anti-trkB 146

\section{P10 anti-trkB 146}

Figure 8. Distribution of trkB immunoreactivity within the cortex during early postnatal development. $A$, P5 sagittal section stained with $2 \mu \mathrm{g} / \mathrm{ml}$ anti-trkB ${ }_{146} . B, C$, Adjacent $\mathrm{P} 10$ sagittal sections stained with either cresyl violet $(B)$ or $1 \mu \mathrm{g} / \mathrm{ml}$ anti-trkB ${ }_{146}(C)$. $D$, P10 sagittal section stained with 1 $\mu \mathrm{g} / \mathrm{ml}$ anti-trkB ${ }_{146}$, showing the pattern of staining within the entire rostral to caudal extent of the cortex. $E$, $F$, P24 sagittal section stained with $5 \mu \mathrm{g} / \mathrm{ml}$ anti-trkB ${ }_{146}$, showing trkB immunoreactivity in sensorimotor $(E)$ and visual $(F)$ cortex. Boxed regions are shown at $2.2 \times$ higher magnification, revealing cells with glial morphology (unfilled arrowheads) predominantly in layer 6 and $W M$ of sensorimotor cortex $(G)$, and scattered large cells with neuronal morphology (arrows) in $W M$ of visual cortex $(H)$. $D$, Dorsal; $H$, hippocampus; $S$, striatum; $S V Z$, subventricular zone; $W M$, white matter. Other abbreviations as in earlier figures. Scale bars: $A, 90 \mu \mathrm{m} ; B, C, 135 \mu \mathrm{m} ; D, 330 \mu \mathrm{m} ; E, F, 57 \mu \mathrm{m}$.

1994) (C. J. Shatz, unpublished observations), and it serves as a waiting compartment for ingrowing corticothalamic axons (McConnell et al., 1989, 1994). Between P38 (Fig. 12F) and P45 (Fig. 12G), the adult-like pattern of trkB immunoreactivity is achieved; heavily stained cells are present throughout all layers of the LGN (Fig. 12H). The neuronal identity of the stained cells was confirmed by ${ }^{3} \mathrm{H}$-thymidine labeling at E24 (data not shown), a time when LGN neurons are being generated in the ferret (Johnson and Casagrande, 1993). Comparison of the immunostaining with cresyl violet staining indicates that even in the adult only a subpopulation of LGN neurons are trkB immunoreactive (data not shown).

The other major retinal target, the superior colliculus, also exhibited immunoreactivity for trkB during early postnatal development. For example, some neurons in the superficial layers of the superior colliculus, those that receive retinal input, stain prominently for trkB between P5 and P11 (data not shown).

\section{DISCUSSION}

Previous studies have found trkB mRNA in such brain structures as adult hippocampus and cerebral cortex (Klein et al., 1989, 1990a, 1990b; Middlemas et al., 1991; Merlio et al., 1992) and embryonic rat cerebral cortex, hippocampus, "proliferative zones," and dorsal thalamus (Ernfors et al., 1992; Ringstedt et al., 1993). TrkB protein has been identified in whole-brain homogenates (Klein et al., 1990a) and tissue slices (Knusel et al., 1994) 

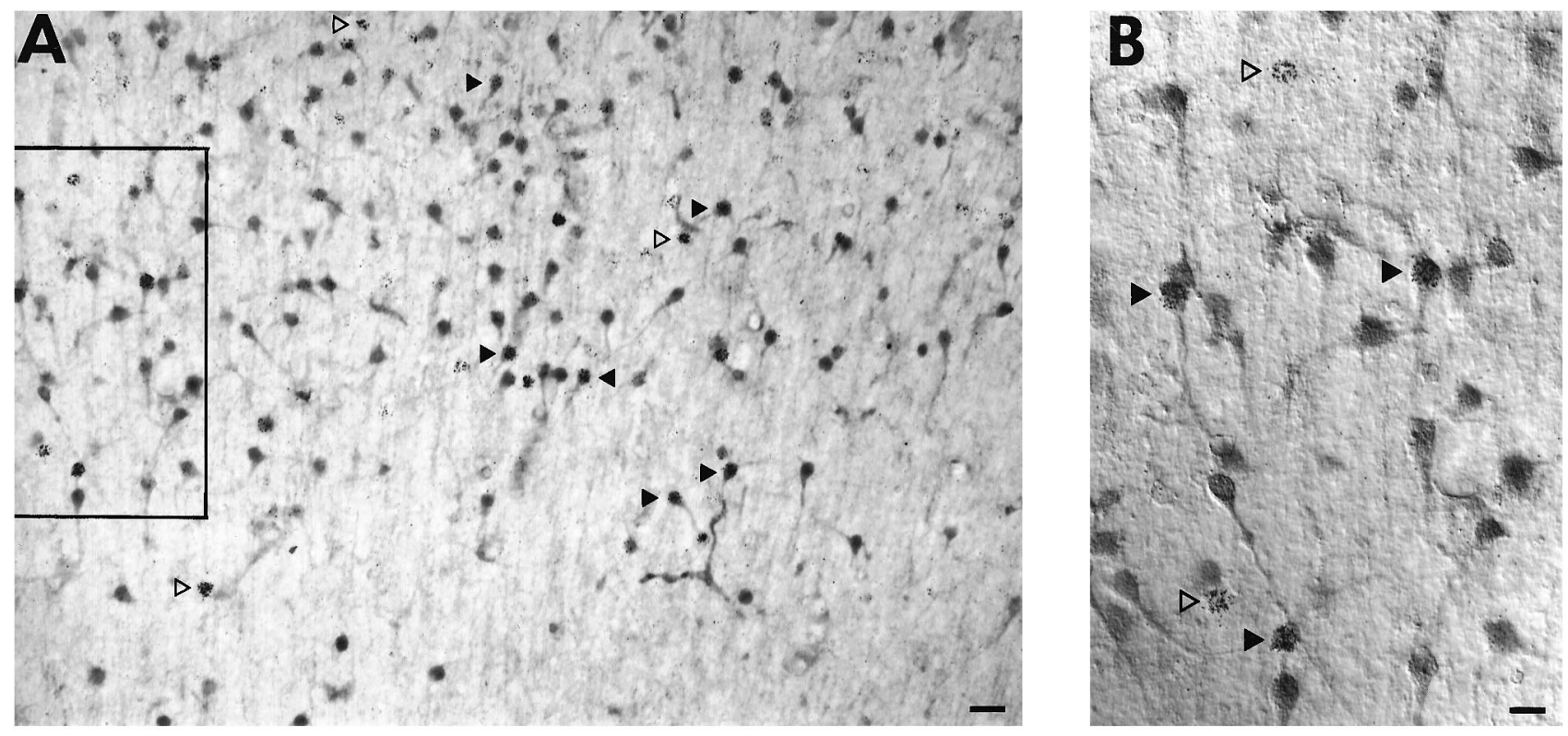

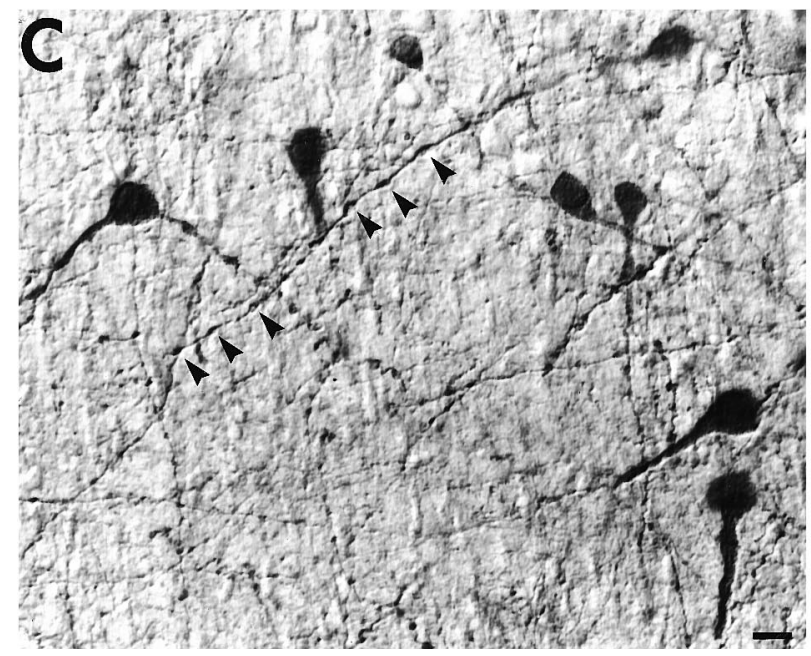

with use of immunoblot techniques and in the visual system through chemical cross-linking of iodinated BDNF (Allendoerfer et al., 1994). Of course, the spatial level of most importance to many aspects of neuronal function is subcellular (e.g., axons, dendrites, and synaptic vesicles), and the cellular and subcellular localization of trkB protein is unapproachable by these methods. In this study we have used immunohistochemical methods to determine the cellular localization of trkB protein in the visual system of the developing ferret. We show that trkB is positioned to mediate responses to both target-derived and locally delivered neurotrophins to regulate neuronal survival, axonal and dendritic arborization, and other aspects of neuronal development.

\section{Specificity of antibodies}

Interpretation of our results depends critically on the specificity of the affinity-purified anti-trkB antibodies. Multiple lines of evidence support the contention that the staining presented here with antibodies anti-trkB $B_{23}$ and anti-trkB $B_{146}$ is specific for trkB protein. (1) Immunostaining of NIH-3T3 cells with both antibodies is dependent on expression of plasmid-encoded trkB protein. (2) Peptide blocking experiments in cell lines and in tissue sec-
Figure 9. $A, B$, The subplate zone in a sagittal section of a P10 ferret stained with anti-trkB ${ }_{146}(1 \mu \mathrm{g} / \mathrm{ml})$, showing ${ }^{3} \mathrm{H}$-thymidine labeled subplate neurons, visualized by emulsion autoradiography, after intrauterine injection of ${ }^{3} \mathrm{H}$-thymidine at E24. $A$, Low-magnification bright-field view. $B$, Higher-magnification view of the same field (see boxed area in $A$ ), using differential interference contrast (DIC) optics. ${ }^{3} \mathrm{H}$-thymidinelabeled subplate neurons that are trkB immunoreactive are seen (filled arrowheads), as well as subplate neurons that are not trkB immunoreactive (unfilled arrowheads). $C$, High-power view of subplate neurons from a sagittal section of a P5 ferret cortex stained with anti-trkB $\mathrm{ex}_{\mathrm{ex}}(2.8$ $\mu \mathrm{g} / \mathrm{ml}$ ), using DIC optics. Processes and varicosities (arrowheads) are clearly stained. Scale bars: $A, 30 \mu \mathrm{m} ; B, 15 \mu \mathrm{m} ; C, 11 \mu \mathrm{m}$.

tions demonstrate that staining with each antibody is epitopespecific. (3) These two antibodies, made against distinct epitopes within the extracellular domain of trkB, show very similar staining patterns throughout development, and this highly specific pattern is replicated by a third anti-trkB antibody (trkBex) made against a trpE-trkB fusion protein. (4) Anti-trkB $\mathrm{B}_{23}$ and anti-trkB $\mathrm{B}_{146}$ recognize pure recombinant trkB on immunoblots (Q. Yan, A. Welcher, M. Radeke, and S. Feinstein; personal communication). (5) All three antibodies recognize full-length and truncated trkB in biochemical assays using deglycosylated material derived from whole ferret cortex. Because the epitopes against which anti$\operatorname{trkB}_{23}$ and anti-trkB ${ }_{146}$ were made overlap with consensus glycosylation sites, we had reasoned that deglycosylation of trkB might enhance the ability of the antibodies to recognize trkB specifically. Moreover, the patterns of recognition of non-trkB bands in immunoblots by the three anti-trkB antibodies are distinct from one another, further evidence that their similar pattern of staining in tissue sections is a consequence of their common recognition of $\operatorname{trkB}$ and not of other proteins. That anti-trkB ${ }_{23}$ and anti-trkB $B_{146}$ stain heavily fixed tissue sections most intensely suggests that they 


\section{P38 Visual Cortex}

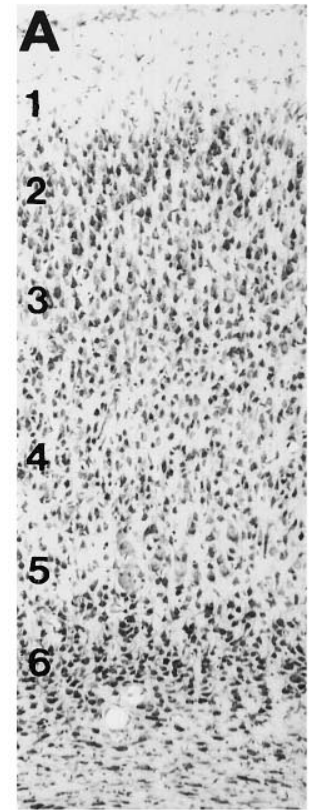

cresyl violet

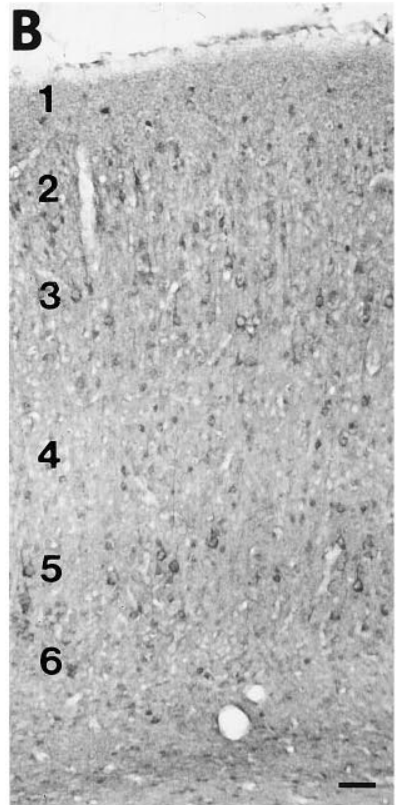

anti-trkB 23

\section{P38 Sensorimotor Cortex}

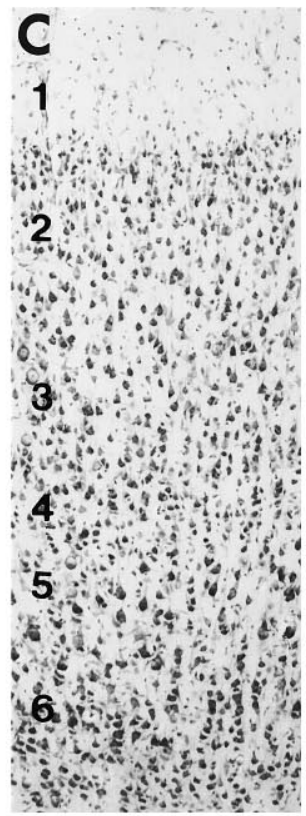

cresyl violet

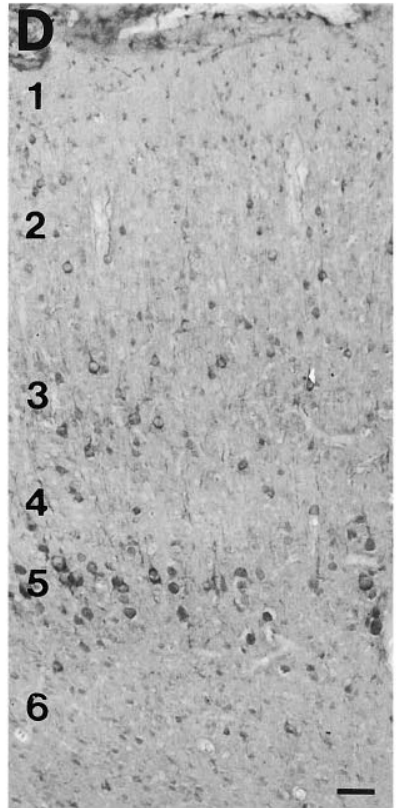

anti-trkB 23

Adult

P45 Cortex

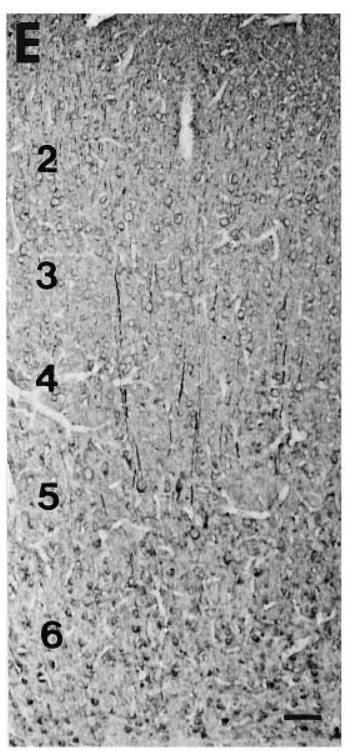

Visual Cortex Sensorimotor Cortex

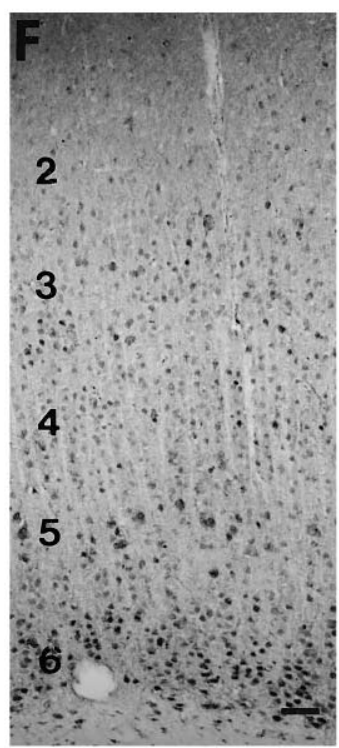

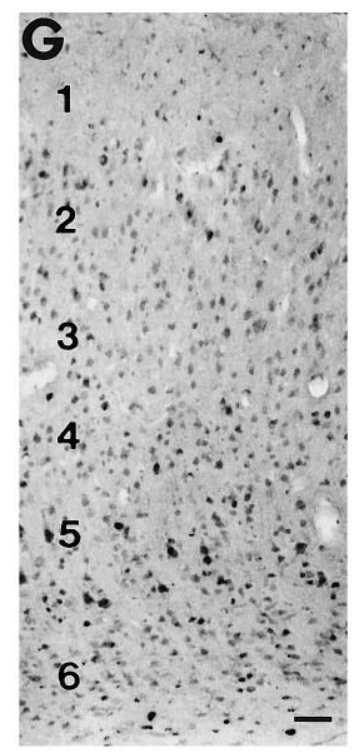

P38, Layer V

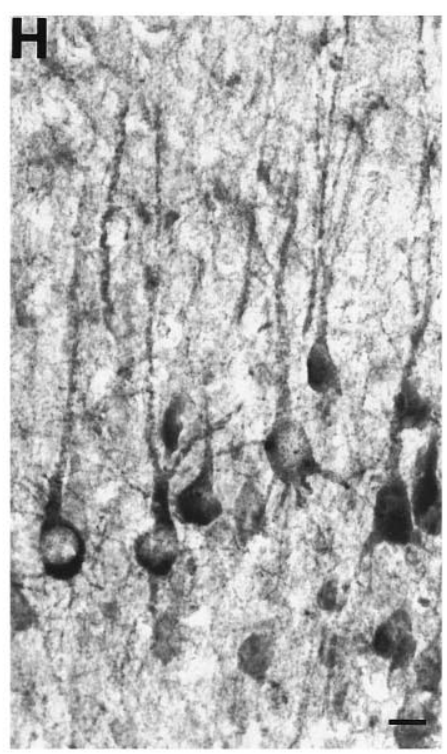

Figure 10. Distribution of trkB immunoreactivity within the cortex during late postnatal development. $A, B$, Sensorimotor cortex in adjacent $\mathrm{P} 38$ sections stained with cresyl violet $(A)$ or anti-trkB ${ }_{23}, 2 \mu \mathrm{g} / \mathrm{ml}(B) . C, D$, Visual cortex in adjacent P38 sections stained with cresyl violet $(C)$ or anti-trkB ${ }_{23}, 1 \mu \mathrm{g} / \mathrm{ml}$ $(D) . E, \mathrm{P} 45$ cortex stained with anti-trkB ${ }_{146}(2 \mu \mathrm{g} / \mathrm{ml}) . F, G$, Adult visual $(F)$ and sensorimotor $(G)$ cortex stained with anti-trkB $146(2 \mu \mathrm{g} / \mathrm{ml}) . H, H$ Higher magnification of trkB-immunoreactive neurons in layer 5 in frontal cortex at P38, showing staining of apical and basal dendrites. All sections are sagittal. Abbreviations as in Figure 5. Scale bars: $A-D, 63 \mu \mathrm{m} ; E, 63 \mu \mathrm{m} ; F, 63 \mu \mathrm{m} ; G, 80 \mu \mathrm{m} ; H, 23 \mu \mathrm{m}$.

recognize particular denatured forms of trkB; their modest recognition of trkB in immunoblots and immunoprecipitation assays may be related to this. (6) Finally, in the adult, the antibody staining pattern is in accord with mRNA data (Klein et al., 1989, 1990a, 1990b; Middlemas et al., 1991; Ernfors et al., 1992; Merlio et al., 1992; Ringstedt et al., 1993); hippocampal and CP neurons and Purkinje cells in the cerebellum are stained. Collectively, these arguments indicate that the immunohistochemistry pre- 


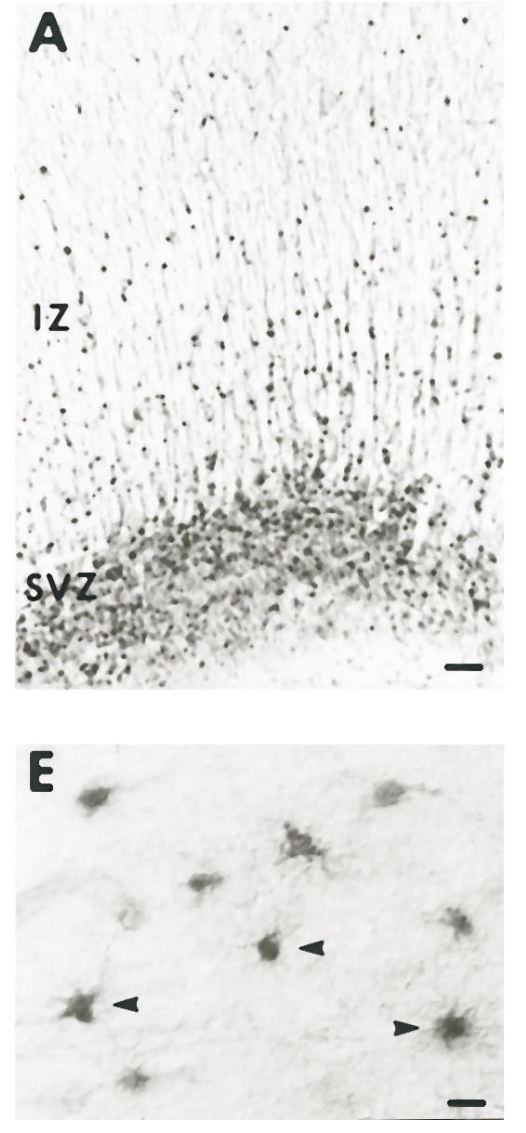

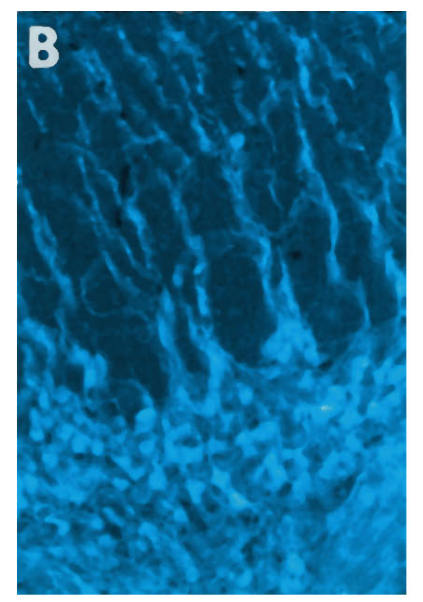
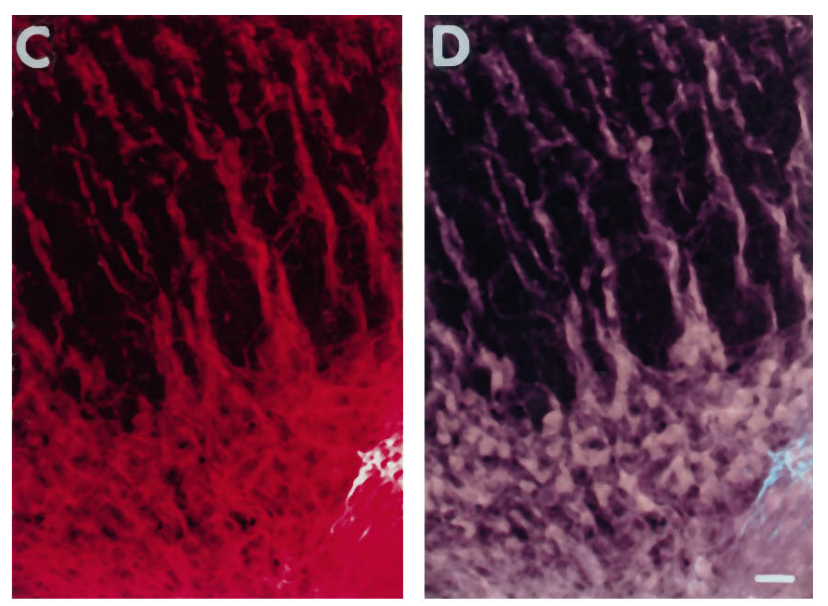

Figure 11. Analysis of trkB immunoreactivity in relation to developing and mature glial populations. $A$, P10 sagittal section stained with anti-trkB ${ }_{146}(1 \mu \mathrm{g} / \mathrm{ml})$ showing trkB-immunoreactive cell bodies and fibers within and emanating from the SVZ. $B-D$, P10 sagittal section, stained with mouse anti-vimentin (1:6) and with anti-trkB ${ }_{146}(2 \mathrm{mg} / \mathrm{ml})$, followed by Texas Red-conjugated anti-mouse $\operatorname{IgG}(1: 200)$ and FITC-conjugated anti-rabbit IgG (1:200). $B$, Pseudo-colored confocal image of vimentin immunoreactivity. $C$, Pseudo-colored confocal image of trkB ${ }_{146}$-immunoreactivity within the identical field as in $B$. $D$, Superimposition of the images shown in $B$ and $C$. Singly labeled adjacent sections showed no bleedthrough between filters under identical conditions to those used in the double-immunofluorescence analysis (data not shown). Immunofluorescence images were obtained using a Bio-Rad 600 confocal microscope. E, Higher-magnification image, using DIC optics, of trkB ${ }_{146}$-immunoreactive cells in the cortical white matter at P24. Arrowheads point to cells with morphology characteristic of mature astrocytes. Abbreviations as in earlier figures. Scale bars: $A, 70 \mu \mathrm{m} ; B-D, 18 \mu \mathrm{m} ; E, 13 \mu \mathrm{m}$. sented here is highly likely to represent specific patterns of trkB expression.

\section{Developmental changes in the subcellular localization of neuronal trkB}

The most striking change in trkB staining over time is the predominance of fiber staining very early in development followed by the appearance of cell body staining postnatally. TrkB-immunoreactive fiber tracts in the cortex very likely include the thalamocortical and corticofugal pathways. One fiber tract travels in the upper IZ, in the subplate region, an area known to be occupied by ascending thalamocortical axons (Ghosh and Shatz, 1992). The other fiber tract runs in the deep IZ, immediately above the VZ, occupied by descending corticofugal fiber tracts (Shatz and Rakic, 1981; DeCarlos and O'Leary, 1992). The cortical neurons whose axons stain for trkB are almost certainly the subplate and deep layer neurons, because they are the only mature cortical neurons at this age and their projections give rise to the descending corticofugal pathways. Biochemical analysis indicates that the BDNF receptor expressed in prenatal cortex is almost exclusively full-length trkB (Allendoerfer et al., 1994), the receptor isoform that initiates signal transduction cascades through tyrosine phosphorylation. The inference that axon fiber tracts present primarily full-length trkB during prenatal development has been confirmed by preliminary immunohistochemical analysis using a battery of full-length and T1-specific antibodies (Cabelli et al., 1994). A similar inference and immunohistochemical confirmation has been made concerning the nature of trkB immunoreactivity on optic tract fibers entering the LGN (putative RGC axons) at E38 (Cabelli et al., 1994). The targets of these deep layer neurons and of RGCs express BDNF; BDNF mRNA is present in the developing superior colliculus (Rickman et al., 1992; Cohen-Cory and Fraser, 1994; Herzog et al., 1994) and LGN (Schoups et al., 1995), targets of layer 5 and 6 neurons, respectively, in the pathway pioneered by subplate axons, and the primary retinal targets as well. The appearance of fulllength trkB on axon fiber tracts during the period when the axons of cortical, thalamic, and retinal projection neurons have just arrived at their targets is consistent with a model of initial dependence on target-derived trophic support. Analysis of BDNF and trkB "knockout" mice has provided evidence of such a role in the development of the peripheral nervous system (PNS) (Klein et al., 1993; Jones et al., 1994), although for reasons ranging from lack of sufficiently detailed morphological or functional analysis of specific neuronal systems to the likelihood of redundant, even compensatory mechanisms, these mice have not yet provided clear answers regarding neurotrophin roles in CNS development.

Subplate and layer 5 pyramidal neurons later come to express trkB immunoreactivity on their somata and dendrites, suggestive of developmental regulation of the subcellular localization of trkB within these neuronal populations. As development proceeds, pyramidal neurons in all cortical layers eventually express trkB. Interestingly, BDNF mRNA is expressed in layer $2 / 3,5$, and 6 neurons during late stages of cortical development (Phillips et al., 1990; Friedman et al., 1991; Huntley et al., 1992; Lein et al., 1995), and cortical expression of NT-4/5 mRNA also increases postnatally (Timmusk et al., 1993). Thus, the widespread appearance of cellular trkB immunostaining postnatally that overlaps with neurotrophin expression may 

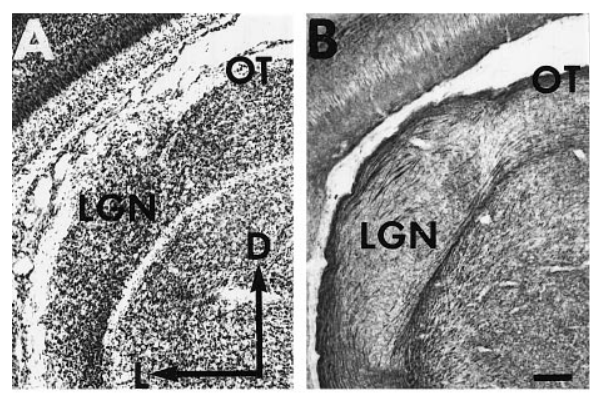

E38 cresyl violet / anti-trkB 23
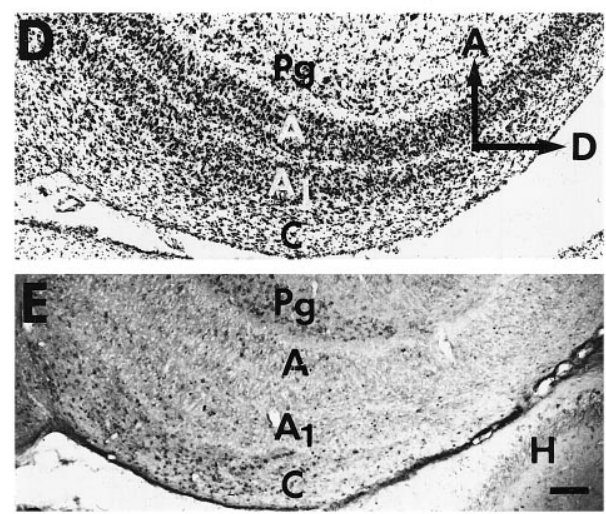

P24 cresyl violet / anti-trkB 23

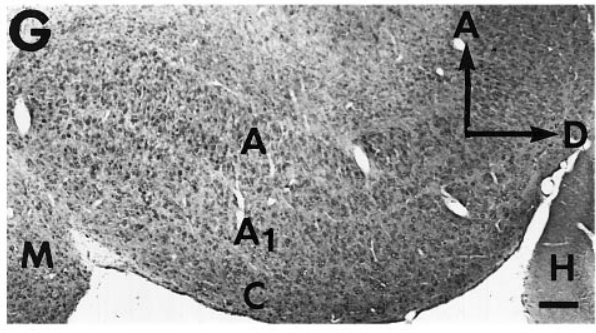

P45 anti-trkB 23
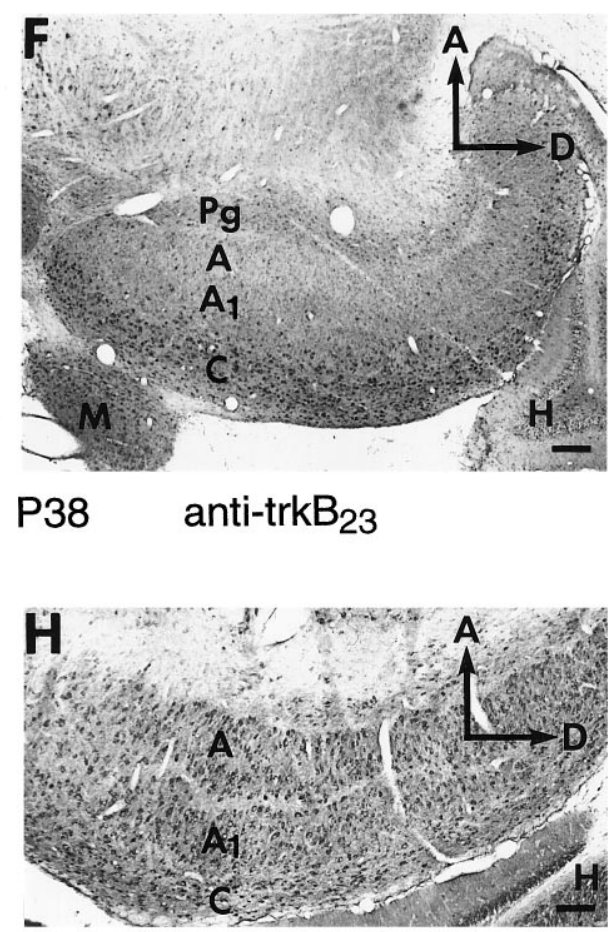

Adult anti-trkB 23
Figure 12. Developmental pattern of trkB immunoreactivity in the developing LGN. $A$, $B$, Adjacent E38 coronal sections stained with cresyl violet $(A)$ or anti-trkB $23(B) . C, \mathrm{P} 5$ sagittal section. $D$, $E$, Adjacent $\mathrm{P} 24$ sagittal sections stained with cresyl violet $(D)$ or anti$\operatorname{trkB}_{23}(E) . F, \mathrm{P} 38$ sagittal section. $G, \mathrm{P} 45$ sagittal section. $H$, Adult sagittal section. All sections were stained with anti-trkB $\mathrm{B}_{23}$ at 0.5 $2.5 \mu \mathrm{g} / \mathrm{ml}$. $A$, A layer; $A 1$, A1 layer; $C$, Clayers; $M$, medial geniculate nucleus; $O T$, optic tract; $P g$, perigeniculate nucleus. Other abbreviations as in earlier figures. Scale bars: $A, B, 140 \mu \mathrm{m} ; C, 95 \mu \mathrm{m} ; D, E, 165 \mu \mathrm{m} ; F, 235$ $\mu \mathrm{m} ; G, 180 \mu \mathrm{m} ; H, 140 \mu \mathrm{m}$. indicate an ability of cells to respond to neurotrophin synthesized locally, through paracrine or autocrine mechanisms [as suggested in the PNS by the work of Schecterson and Bothwell (1992) and Acheson et al. (1995)], delivered from neurons in other cortical layers or from glia, or delivered anterogradely (von Bartheld et al., 1996) from subcortical inputs. This contrasts with the earlier responsiveness to target-derived neurotrophin suggested by prenatal fiber staining. Changes in trkB subcellular localization, then, could play an important role in regulating neuronal dependence on and responsiveness to target neurons.

We have obtained preliminary evidence that both forms of trkB, full-length and trkB.T1, are present on the cell body and dendrites of cortical neurons (Cabelli et al., 1994). Because the functional role of trkB.T1 remains an open question, and in the absence of information on the relative distributions of these two forms of trkB within individual neurons, it is not yet possible to predict the effect this has on cortical responsiveness to trkB ligands. There is a striking correspondence, however, between the subpopulations of cortical neurons that demonstrate cell body immunoreactivity for trkB in this study and the cellular pattern of c-fos induction after the addition of trkB ligands to cortical slices at varying developmental stages, recently presented by Pearlman et al. (1995). In contrast, the effects of trkB ligands applied to P14 ferret cortical slices on dendritic morphology in layers 4-6 (McAllister et al., 1995) are inconsistent with the trkB distribution we report here, if one assumes that the morphological response in a particular neuron is based on the presence of trkB on the cell body of that neuron.

\section{Selective trkB expression by subsets of neurons}

Within a given structure, early-generated neurons, such as subplate neurons in cortex, seem to be first to express trkB on their cell bodies. Cortical layer 5 neurons, which along with subplate neurons are the first cortical neurons to be immunoreactive for trkB, also exhibit a mature phenotype very early in development. They have established extensive projections to the superior colliculus as early as P14 (McConnell et al., 1989) and express microtubule-associated protein 2 even before layer 6 neurons 
(Ghosh and Shatz, 1992). Thus, cell body accumulation of trkB could be driven partly by cellular maturation. In the LGN, the developmental sequence and timing of cellular trkB immunoreactivity, PGN and C-layers early, followed by all layers in the adult, parallels that found for glutamic acid decarboxylase immunoreactivity in the developing cat (Shotwell et al., 1986), suggesting that GABAergic interneurons may be the first cells in the LGN to acquire trkB on their cell bodies. Although thalamocortical axons express trkB very early, A-layer neurons, presumably including those that project to visual cortex, do not stain robustly for trkB until late in development, between P38 and P45 in the ferret, coincident with the segregation of LGN afferents into OD patches in visual cortex (E. Finney and C. J. Shatz, unpublished observations). Again, the appearance of trkB on the cell soma correlates with the acquisition of adult-like neuronal properties. By analogy with the shift in subcellular localization of trkB suggested for cortical neurons during early development, it is possible that A-layer projection neurons, lightly stained for trkB during the initial period of OD segregation, express trkB protein on their axon terminals in visual cortex, as suggested by the ability of intracortically infused NT-4/5 to inhibit formation of OD patches (Cabelli et al., 1995) and prevent the reduction in LGN cell soma size associated with monocular deprivation (Riddle et al., 1995), both of which can be interpreted in terms of neurotrophin action at geniculocortical synapses. (Of course, it remains possible that these effects are indirect, secondary to action on cortical neurons that express trkB.)

A recent report concerning trkB immunoreactivity in adult rat visual cortex (Cellerino et al., 1996) corroborates our finding that late in development trkB immunoreactivity is particularly prominent in pyramidal neurons in layers $2 / 3$ and 5 . Interestingly, the authors also determined that many parvalbumin-positive cortical neurons express trkB. Parvalbumin expression is thought to characterize one subpopulation of GABAergic interneurons (Celio, 1986; Demeulemeester et al., 1991), leading to the insight that trkB ligands may be able to modulate the activity of certain inhibitory as well as excitatory cortical neurons, and providing an additional possible target for BDNF and/or NT-4/5 in the regulation of OD segregation and plasticity.

Often only a subset of neurons in a given population express trkB, as seen in the subplate, the LGN, and layer 5 at certain developmental stages. The significance of this heterogeneity is not understood. Different subpopulations of neurons in these structures might express different neurotrophin receptors, as shown for dorsal root ganglia (Carroll et al., 1992; Ruit et al., 1992; Molliver et al., 1995); some might express no neurotrophin receptor at all. Lack of trkB immunoreactivity on individual subplate neurons could be a consequence or cause of a different cellular or neuronal developmental fate, even including cell death.

\section{Expression of trkB by subplate neurons}

One rationale for performing this study was to determine whether subplate neurons express a neurotrophin receptor in addition to $\mathrm{p} 75$. We have shown that this is indeed the case; however, expression of trkB on subplate neurons seems to reach its apex at P10, after p75 expression has begun to decline (Allendoerfer et al., 1990). In one model of neurotrophin receptor function, p75 and the appropriate trk receptor molecule, co-expressed by a given neuron, are both required for an optimal functional response, with the trk conferring neurotrophin specificity (Rodriguez-Tébar et al., 1990). It is possible, then, that changes in expression of either receptor type might be relevant to altered neurotrophin responsiveness during development. The timing of expression of trkB alone, however, puts the BDNF/NT-4/5/trkB system in an opportune position to mediate subplate neuron survival; subplate cell death seems to occur quite late in the ferret cortex, with a substantial amount occurring after P24 (Hohn et al., 1993). Preliminary analysis suggests that the fraction of ${ }^{3} \mathrm{H}$-thymidinelabeled subplate neurons that are not trkB immunoreactive has increased by $\mathrm{P} 18$ and $\mathrm{P} 24$, over that at P10, consistent at least with a developmentally regulated loss of trkB from subplate neurons preceding their death.

\section{Summary}

The results presented here demonstrate that numerous neuronal cell types are immunoreactive for trkB at different times in the ferret visual system and that the subcellular distribution of trkB within many of these cells shifts from the axon fiber tract to include somata and dendritic localization as development proceeds. These data suggest multiple and changing roles for ligands of trkB in the developing visual system and set the stage for future perturbation studies of trkB action.

\section{REFERENCES}

Acheson A, Conover JC, Fandl JP, DeChiara TM, Russell M, Thadani A, Squinto SP, Yancopoulos GD, Lindsay RM (1995) A BDNF autocrine loop in adult sensory neurons prevents cell death. Nature 374:450-453.

Allendoerfer KL, Shatz CJ (1994) The subplate, a transient neocortical structure: its role in the development of connections between thalamus and cortex. Annu Rev Neurosci 17:185-218.

Allendoerfer KL, Shelton DL, Shooter EM, Shatz CJ (1990) Nerve growth factor receptor immunoreactivity is transiently associated with the subplate neurons of the mammalian cerebral cortex. Proc Natl Acad Sci USA 87:187-190.

Allendoerfer KL, Cabelli RJ, Escandón E, Kaplan DR, Nikolics K, Shatz CJ (1994) Regulation of neurotrophin receptors during the maturation of the mammalian visual system. J Neurosci 14:1795-1811.

Bozzi Y, Pizzorusso T, Cremisi F, Comelli MC, Berardi N, Maffei L (1993) Monocular deprivation decreases the expression of BDNF mRNA in the rat visual cortex. Soc Neurosci Abstr 19:6.

Cabelli RJ, Radeke MJ, Wright A, Allendoerfer KA, Feinstein SC, Shatz CJ (1994) Developmental patterns of localization of full-length and truncated trkB proteins in the mammalian visual system. Soc Neurosci Abstr 20:37.

Cabelli RJ, Hohn A, Shatz CJ (1995) Inhibition of ocular dominance column formation by infusion of NT-4/5 or BDNF. Science 267:1662-1666.

Carroll SL, Silos-Santiago I, Frese SE, Ruit KG, Milbrandt J, Snider WD (1992) Dorsal root ganglion neurons expressing trk are selectively sensitive to NGF deprivation in utero. Neuron 9:779-788.

Castrén E, Zafra F, Thoenen H, Lindholm D (1992) Light regulates expression of brain-derived neurotrophic factor mRNA in rat visual cortex. Proc Natl Acad Sci USA 89:9444-9448.

Celio MR (1986) Parvalbumin in most gamma-aminobutyric acid containing neurons of the rat cerebral cortex. Science 231:995-997.

Cellerino A, Maffei L, Domenici L (1996) The distribution of brainderived neurotrophic factor and its receptor trkB in parvalbumincontaining neurons of the rat visual cortex. Eur J Neurosci 8:1190-1197.

Chun JJM, Shatz CJ (1989) Interstitial cells of the adult neocortical white matter are the remnant of the early generated subplate population. J Comp Neurol 282:555-569.

Cohen-Cory S, Fraser SE (1994) BDNF in the development of the visual system of Xenopus. Neuron 12:747-761.

Cohen-Cory S, Fraser SE (1995) Effects of brain-derived neurotrophic factor on optic axon branching and remodelling in vivo. Nature 378:192-196.

Cucchiaro J, Guillery RW (1984) The development of the retinogeniculate pathways in normal and albino ferrets. Proc R Soc Lond [Biol] 223:141-164. 
De Carlos JA, O'Leary DDM (1992) Growth and targeting of subplate axons and establishment of major cortical pathways. J Neurosci 12:1194-1211.

Demeulemeester H, Arckens L, Vandesande F, Orban GA, Heizenmann CW, Pochet R (1991) Calcium binding proteins and neuropeptides as molecular markers of GABAergic interneurons in the cat visual cortex. Exp Brain Res 84:538-544.

DiStefano PS, Friedman B, Radziejewski C, Alexander C, Boland P, Schick CM, Lindsay RM, Wiegand SJ (1992) The neurotrophins BDNF, NT-3 and NGF display distinct patterns of retrograde axonal transport in peripheral and central neurons. Neuron 8:983-993.

Edwards MA, Yamamoto M, Caviness Jr VS (1990) Organization of radial glia and related cells in the developing murine CNS: an analysis based upon a new monoclonal antibody marker. Neuroscience 36:121-144.

Elliott JF, Albrecht GR, Gilladoga A, Handunnetti SM, Neequaye J, Lallinger G, Minjas JN, Howard RJ (1990) Genes for Plasmodium falciparum surface antigens cloned by expression in COS cells. Proc Natl Acad Sci USA 87:6363-6367.

Engel AK, Müller CM (1989) Postnatal development of vimentinimmunoreactive radial glial cells in the primary visual cortex of the cat. J Neurocytol 18:437-450.

Ernfors P, Merlio JP, Persson H (1992) Cells expressing messenger RNA for neurotrophins and their receptors during embryonic rat development. Eur J Neurosci 4:1140-1158.

Friedman WJ, Olson L, Persson H (1991) Cells that express brainderived neurotrophic factor mRNA in the developing postnatal rat brain. Eur J Neurosci 3:688-697.

Ghosh A, Shatz CJ (1992) Pathfinding and target selection by developing geniculocortical axons. J Neurosci 12:39-55.

Henderson Z, Finlay BL, Wikler CK (1988) Development of ganglion cell topography in ferret retina. J Neurosci 8:1194-1205.

Herzog KH, Bailey K, Barde YA (1994) Expression of the BDNF gene in the developing visual system of the chick. Development 120:1643-1649.

Hickey TL, Whikehart DR, Jackson CA, Hitchcock PF, Peduzzi JD (1983) Tritiated thymidine experiments in the cat: a description of techniques and experiments to define the time-course of radioactive thymidine availability. J Neurosci Methods 8:139-147.

Hohn A, Allendoerfer KA, Torojan-Raymond A, Shatz CJ (1993) Survival of subplate neurons in cultures of developing neocortex. Soc Neurosci Abstr 19:1504.

Huntley GW, Benson DL, Jones EG, Isackson PJ (1992) Developmental expression of brain derived neurotrophic factor mRNA by neurons of fetal and adult monkey prefrontal cortex. Dev Brain Res 70:53-63.

Jackson CA, Peduzzi JD, Hickey TL (1989) Visual cortex development in the ferret. I. Genesis and migration of visual cortical neurons. J Neurosci 9:1242-1253.

Jelsma TN, Friedman HH, Berkelaar M, Bray GM, Aguayo AJ (1993) Different forms of the neurotrophin receptor trkB mRNA predominate in rat retina and optic nerve. J Neurobiol 24:1207-1214.

Johnson JE, Barde Y-A, Schwab M, Thoenen H (1986) Brain-derived neurotrophic factor supports the survival of cultured rat retinal ganglion cells. J Neurosci 6:3031-3038.

Johnson JK, Casagrande VA (1993) Prenatal development of axon outgrowth and connectivity in the ferret visual system. Vis Neurosci 10:117-130.

Jones KR, Farinas I, Backus C, Reichardt LF (1994) Targeted disruption of the BDNF gene perturbs brain and sensory neuron development but not motor neuron development. Cell 76:989-999.

Kaplan DR, Martin-Zanca D, Parada LF (1991) Tyrosine phosphorylation and tyrosine kinase activity of the trk proto-oncogene product induced by NGF. Nature 350:158-160.

Klein R, Parada LF, Coulier F, Barbacid M (1989) trkB, a novel tyrosine protein kinase receptor expressed during mouse neural development. EMBO J 8:3701-3709.

Klein R, Conway D, Parada LF, Barbacid M (1990a) The trkB tyrosine protein kinase codes for a second neurogenic receptor that lacks the catalytic kinase domain. Cell 61:647-656.

Klein R, Martin-Zanca D, Barbacid M, Parada LF (1990b) Expression of the tyrosine kinase receptor gene trkB is confined to the murine embryonic and adult nervous system. Development 109:845-850.

Klein R, Smeyne RJ, Wurst W, Long LK, Auerbach BA, Joyner AL, Barbacid M (1993) Targeted disruption of the trkB neurotrophin receptor gene results in nervous system lesions and neonatal death. Cell 75:113-122.
Knüsel B, Rabin S, Hefti F, Kaplan DR (1994) Regulated neurotrophin responsiveness during neuronal migration and early differentiation. J Neurosci 14:1542-1554.

Lein E, Hohn A, Shatz CJ (1995) Reciprocal laminar localization and developmental regulation of BDNF and NT-3 mRNA during visual cortex development. Soc Neurosci Abstr 21:1795.

Levay S, Stryker MP, Shatz CJ (1978) Ocular dominance columns and their development in layer IV of the cat's visual cortex: a quantitative study. J Comp Neurol 179:223-244.

Linden DC, Guillery RW, Cucchiaro J (1981) The dorsal lateral geniculate nucleus of the normal ferret and its postnatal development. J Comp Neurol 203:189-211.

McAllister AK, Lo DC, Katz LC (1995) Neurotrophins regulate dendritic growth in developing visual cortex. Neuron 15:791-803.

McConnell SK, Ghosh A, Shatz CJ (1989) Subplate neurons pioneer the first axon pathway from the cerebral cortex. Science 245:978-982.

McConnell SK, Ghosh A, Shatz CJ (1994) Subplate pioneers and the formation of descending connections from cerebral cortex. J Neurosci 14:1892-1907.

Merlio JP, Ernfors P, Jaber M, Persson H (1992) Molecular cloning of rat trkC and distribution of cells expressing messenger RNAs for members of the trk family in the rat central nervous system. Neuroscience 51:513-532.

Middlemas DS, Lindberg RA, Hunter T (1991) TrkB, a neural receptor protein-tyrosine kinase: evidence for a full-length and two truncated receptors. Mol Cell Biol 11:143-153.

Mitrofanis J (1994) Development of the thalamic reticular nucleus in ferrets with special reference to the perigeniculate and perireticular cell groups. Eur J Neurosci 6:253-263.

Molliver D, Radeke MJ, Feinstein SC, Snider WD (1995) Presence or absence of trkA protein distinguishes subsets of small sensory neurons with unique cytochemical characteristics and dorsal horn projections. J Comp Neurol 361:404-411.

O'Leary DDM, Fawcett JW, Cowan WM (1986) Topographic targeting errors in the retinocollicular projection and their elimination by selective ganglion cell death. J Neurosci 6:3692-3705.

Pearlman AL, Snider WD, Osborne PA, Brunstrom JE (1995) Neurotrophin-4 induces the production of c-fos in specific populations of developing cortical neurons that express trkB. Soc Neurosci Abstr 21:546.

Phillips HS, Hains JM, Laramee GR, Rosenthal A, Winslow JW (1990) Widespread expression of BDNF but not NT3 by target areas of basal forebrain cholinergic neurons. Science 250:290-294.

Rickman DW, Brecha NC (1995) Expression of the proto-oncogene, trk, receptors in the developing rat retina. Vis Neurosci 12:215-222.

Rickman DW, Lauterborn J, Brecha N, Gall C (1992) Expression of low-affinity NGF-receptor-immunoreactivity and BDNF and NT-3 mRNAs in developing rat retina and superior colliculus. Soc Neurosci Abstr 18:225.

Riddle DR, Lo DC, Katz LC (1995) NT-4-mediated rescue of lateral geniculate neurons from effects of monocular deprivation. Nature 378:189-191.

Ringstedt T, Lagercrantz H, Persson H (1993) Expression of members of the trk family in the developing postnatal rat brain. Brain Res 72:119-131.

Rocamora N, Welker E, Soriano E, Planas AM, Van der Loos H (1993) Upregulation of BDNF mRNA expression in the barrel cortex of adult mice following whisker stimulation. Soc Neurosci Abstr 19:259.

Rodriguez-Tébar A, Jeffrey PL, Thoenen H, Barde Y-A (1989) The survival of chick retinal ganglion cells in response to brain-derived neurotrophic factor depends on their embryonic age. Dev Biol 136:296-303.

Rodriguez-Tabar A, Dechant G, Barde Y-A (1990) Binding of brainderived neurotrophic factor to the nerve growth factor receptor. Neuron 4:487-492.

Ruit KG, Elliott JL, Osborne PA, Yan Q, Snider WD (1992) Selective dependence of mammalian dorsal root ganglion neurons on nerve growth factor during embryonic development. Neuron 8:573-587.

Schecterson LC, Bothwell M (1992) Novel roles for neurotrophins are suggested by BDNF and NT-3 mRNA expression in developing neurons. Neuron 9:449-463.

Schmechel DE, Rakic P (1979) A golgi study of radial glial cells in developing monkey telencephalon: morphogenesis and transformation into astrocytes. Anat Embryol 156:115-152. 
Schoups AA, Elliot RC, Friedman WJ, Black IB (1995) NGF and BDNF are differentially modulated by visual experience in the developing geniculocortical pathway. Dev Brain Res 86:326-334.

Shatz CJ (1983) The prenatal development of the cat's retinogeniculate pathway. J Neurosci 3:482-499.

Shatz CJ, Rakic P (1981) The genesis of efferent connections from the visual cortex of the fetal rhesus monkey. J Comp Neurol 196:287-307.

Shotwell SL, Shatz CJ, Luskin MB (1986) Development of glutamic acid decarboxylase immunoreactivity in the cat's lateral geniculate nucleus. J Neurosci 6:1410-1423.

Timmusk T, Belluardo N, Metsis M, Persson H (1993) Widespread and developmentally regulated expression of neurotrophin-4 mRNA in rat brain and peripheral tissues. Eur J Neurosci 5:605-613.

Voigt T (1989) Development of glial cells in the cerebral wall of ferrets: direct tracing of their transformation from radial glia into astrocytes. J Comp Neurol 289:74-88.

von Bartheld CS, Byers MR, Williams R, Bothwell M (1996) Anterograde transport of neurotrophins and axodendritic transfer in the developing visual system. Nature 379:830-833.

Wigler M, Sweet R, Sim GK, Wold B, Pellicer A, Lacy E, Maniatis T, Silverstein S, Axel R (1979) Transformation of mammalian cells with genes from procaryotes and eucaryotes. Cell 16:777-785.

Williams RW, Rakic P (1988) Elimination of neurons from the rhesus monkey's lateral geniculate nucleus during development. J Comp Neurol 272:424-436.

Williams RW, Bastiani MJ, Lia B, Chalupa LA (1986) Growth cones, dying axons, and developmental fluctuations in the fiber population of the cat's optic nerve. J Comp Neurol 246:32-69. 